Trakya Eğitim Dergisi

Cilt 10, Sayı 3

Eylül 2020, 815-834

Gelis Tarihi: 17.11.2019

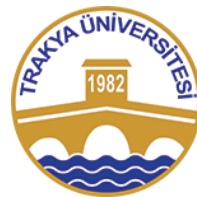

ISSN: $2630-6301$

Doi:10.24315/tred.647828

Araşttrma Makalesi

Research Article
Trakya Journal of Education

Volume 10, Issue 3

September 2020, 815-834

Yayına Kabul Tarihi:11.05.2020

\title{
Ergenlerin Okula Aidiyet Duyguları ve Başa Çıkma Stratejilerinin İncelenmesi
}

\author{
Examining Adolescents' Sense of School Belonging and Coping Strategies
}

\section{Özge AKINCI GÖKDAL ${ }^{1}$, Betül DÜŞÜNCELI' $\dot{I}^{2}$}

ÖZ: Araştırma ergenlerin okula aidiyet duyguları ve başa çıkma stratejilerini belirlemeyi amaçlamaktadır. Araştırmanın çalışma grubunu Kırklareli'nin Lüleburgaz ilçesinde üç farklı türde devlet okulunda lise kademesinde öğrenim gören 1214 öğrenci (738 kız, 476 erkek) oluşturmaktadır. Veriler Okula Aidiyet Duygusu Ölçeği, Ergenler İçin Başa Çıkma Stratejileri Ölçeği ve Kişisel Bilgi Formuyla toplanmıştır. Veriler sosyal bilimler için kullanılan SPSS.17 istatistik paket programı ile analiz edilmiştir. Ergenlerin okula aidiyet duygusu boyutu ile aktif başa çıkma boyutu arasında orta düzeyde pozitif yönde istatistiksel olarak anlamlı bir ilişki bulunmuştur. Ergenlerin okula aidiyet duygusu boyutu ile kaçınan başa çıkma ve olumsuz başa çıkma boyutları arasında negatif yönde istatistiksel olarak anlamlı ancak düşük düzeyde bir ilişki bulunmaktadır. Ergenlerin reddedilmişlik duygusu boyutu ile aktif başa çıkma boyutu arasında negatif yönde istatistiksel olarak anlamlı ancak düşük düzeyde bir ilişki bulunmuştur. Ergenlerin reddedilmişlik duygusu boyutu ile kaçınan başa çıkma ve olumsuz başa çıkma boyutları arasında pozitif yönde istatistiksel olarak anlamlı ancak düşük düzeyde bir ilişki bulunmaktadır. Okula ait olma değişkeninde cinsiyet, okul türü, sınıf düzeyi, algılanan akademik başarı düzeyi ve lise seçim sürecine; başa çıkma değişkeninde okul türü, sınıf düzeyi, algılanan akademik başarı, lise seçim sürecine göre anlamlı fark saptanmıştır. Bulgular alanyazın çerçevesinde tartışılmıştır.

Anahtar sözcükler: Ergen, okula aidiyet duygusu, başa çıkma stratejileri

\begin{abstract}
The research aims to determine adolescents' sense of belonging and coping strategies. The study group of the study consists of 1214 students ( 738 girls, 476 boys) studying in three different types of public schools in Lüleburgaz district of Kurklareli. The data were collected using the School Feeling Scale, the Coping Strategies for Adolescents Scale and the Personal Information Form. The data were analyzed with SPSS.17 statistics package program used for social sciences. A moderately positive and statistically significant relationship was found between adolescents' sense of belonging and active coping. There is a statistically significant but low level relationship between adolescents' sense of belonging to school and avoided coping and negative coping dimensions. A negative but statistically significant relationship was found between adolescents' sense of rejection and active coping. There is a statistically significant but low level relationship between adolescents' sense of rejection and avoided coping and negative coping dimensions. In the variable of belonging to school, gender, school type, class level, perceived academic success level and high school selection process; There was a significant difference in coping variable according to school type, class level, perceived academic success, high school selection process. Findings are discussed within the framework of the literature.
\end{abstract}

Keywords: Adolescent, sense of school belonging, coping strategies.

Bu makaleye atıf vermek için:

Akıncı-Gökdal, Ö. \& Düşünceli, B. (2020). Ergenlerin okula aidiyet duyguları ve başa çıkma stratejilerinin incelenmesi. Trakya Eğitim Dergisi, 10(3), 815-834

Cite this article as:

Akıncı-Gökdal, Ö. \& Düşünceli, B. (2020). Examining adolescents' sense of school belonging and coping strategies. Journal of Trakya Education, 10(3), 815-834.

\section{EXTENDED ABSTRACT}

\section{Introduction}

The research aims to determine adolescents' sense of belonging to school and coping strategies. The study group consisted of 1214 students ( 738 girls, 476 boys) attending three different types of public schools under the Ministry of National Education in Lüleburgaz district of Kirklareli. In order to collect data, Sense of Belonging to School Scale, Coping Strategies Scale for Adolescents and Personal Information Form were used.

$1^{*}$ Bu makale, ikinci yazarın danışmanlığında birinci yazarın hazırladığı yüksek lisans tezinden üretilmiştir.

${ }^{1}$ Öğretmen, MEB, e-posta: poyrazpoyraz93@ hotmail.com, ORCID no: 0000-0002-7597-661X

2 Dr. Öğr. Üyesi, Sakarya Üniversitesi, e-posta: bbayraktar@ sakarya.edu.tr, ORCID no: 0000-0002-6794-8811 


\section{Method}

The research was carried out in a descriptive model using quantitative data collection techniques in order to examine adolescents' feelings of belonging to the school and coping strategies. The screening model is a research approach that reveals a situation that has existed in the past or present. The screening model conducted on large groups is the study of the attitudes of individuals about a case or event.

\section{Discussion and Conclusion}

The sense of belonging to the school variable consists of the dimensions of belonging to the school and sense of rejection. The coping strategies variable consists of active coping, avoiding coping and negative coping dimensions. A moderate positive correlation was found between adolescents' sense of belonging to school and active coping dimension. There was a statistically significant but low level relationship between adolescents' sense of belonging to school and avoidance coping and negative coping dimensions. There was a statistically significant but low-level relationship between adolescents' sense of rejection and active coping dimensions. There was a statistically significant but low-level relationship between adolescents' sense of rejection and avoidant coping and negative coping dimensions. In this study, it was found that the scores obtained from male adolescents in terms of sense of belonging to school were significantly higher than the scores of female adolescents. When the findings were examined, it was seen that 9th grade adolescents had higher sense of belonging to school than adolescents in upper classes and 10th grade adolescents compared to 12th grade adolescents. In addition, as the grade level increased, the scores of the sense of rejection dimension increased. Another finding of the study is that while the highest sense of belonging to school dimension belongs to adolescents in Science High School, the lowest sense of belonging to school dimension belongs to adolescents in Vocational High School. In addition, the highest rejection sense dimension score belongs to adolescents in Vocational High School, while the lowest rejection sense dimension score belongs to adolescents in Science High School. In this study, it was found that the highest sense of belonging to school dimension was found to be higher than the adolescents who perceived the achievement level as high and the lowest sense of belonging to the school dimension was found to belong to the adolescents who perceived the achievement level as low. In addition, the highest rejection sense dimension score belongs to the adolescents who perceive the achievement level as low, while the lowest rejection sense dimension score belongs to the adolescents who perceive the achievement level as high. When the findings related to the high school selection process of the adolescents are examined, it is seen that the adolescents who make their own choice according to their family and their own desire have higher scores of sense of belonging to school than other adolescents. In addition, it was seen that adolescents who stated that they made the selection process according to points had higher rejection sense scores than other adolescents. When coping strategies of adolescents were analyzed according to gender variable, it was found that active coping, avoiding coping and negative coping subscales did not show statistically significant difference according to gender. In the research findings, it is seen that the avoidant coping scores, which is the sub-dimension of the coping strategies of adolescents, differ significantly according to the grade level of adolescents. This difference was between the 10th grade adolescents and the 9th and 12th grade adolescents, and the 10th grade adolescents 'avoidance coping dimension scores were significantly higher than the 9th and 12th grade adolescents' avoiding coping dimension scores. There is a statistically significant difference in Active Coping dimension according to school type. According to this, adolescents studying in Science High School with the highest score in the coping strategies' active coping sub-dimension were found to have the lowest scores for adolescents in Vocational High School. When the coping strategies of adolescents were examined according to perceived success level, the scores of adolescents who perceived the level of achievement as low in active coping dimension were statistically lower than the scores of adolescents who perceived the achievement level as medium and high. In the negative coping dimension, the scores of the adolescents who perceived the achievement level as low were statistically higher than the scores of the adolescents who perceived the achievement level as medium and high. When coping strategies with high school selection process, it was seen that active coping dimension scores of those who chose according to their own and family's wishes were statistically higher. In addition, negative coping dimension scores of those who prefer according to their own and family's wishes were found to be statistically lower. When coping strategies with high school selection process, it was seen that active 
coping dimension scores of those who chose according to their own and family's wishes were statistically higher. In addition, negative coping dimension scores of those who prefer according to their own and family's wishes were found to be statistically lower. The findings were discussed within the framework of the literature.

\section{Gíriş}

Yaşam içerisinde birçok gelişimsel süreç barındırır; bebeklik, çocukluk, ergenlik, yetişkinlik, yaşl1lık. Bu gelişimsel süreçler içinde de "ergenlik" en sancılı ve zorlu geçen dönemlerden birisidir. Temelde ergenlik dönemine fizyolojik ve hormonal gelişim, toplumsal süreçler, ekonomik kararlılık ya da duygusal gelişim açısından yaklaşılır. Ancak ergenlik dönemini zor kılan faktör, tüm bu etkenlerin birleşimi olarak karşımıza çıkmaktadır. Ergenlik her bireyin karşı karşıya gelmesi gereken bir takım görevleri içinde barındıran bir dönem olarak değerlendirilebilir. Bu görevlerin içeriğini eğitim, olgunlaşma, değer anlayışı oluşturmak, sağlıklı iletişim kurabilmek vb. oluşturmaktadır. Bu nedenle ergenliği sadece yaş almak şeklinde düşünmek doğru değildir. Ergenliğin en geniş şekilde ele alınması için bireyin tüm gelişim alanlarını ele alan bir pencereden bakmak faydalı olacaktır (Adams, 1995). Gelişim alanlarının önemli bir öğesi de sosyal gelişim alanıdır.

Bireyin ilk sosyal çevresini anne-babası oluşturur. Çocukluktan ergenliğe geçiş aşamasına kadar birey ailesinin yaşamlarını ve tutumlarını yansıtırlar. Ancak ergenlik döneminden itibaren ailesinin ideallerinden ve yaklaşımlarından vazgeçmiş görünür. Ancak bu noktada bile aileye gereksinim duyduğu ve yanında olunmasını beklediği ifadeler kullanırlar (Yavuzer, 2008). Okula başlama ile arkadaşlarının birey üzerinde etkisi görülmeye başlamakta ve bu etki ergenlik döneminde üst seviyelere ulaşmaktadır.

$\mathrm{Bu}$ dönemde arkadaşlarla kurulan ilişki anne-baba ile kurulan ilişkiden farklıdır; anne-baba otorite figürü iken arkadaşlık ilişkilerinde eşitlikçi bir sosyal teması deneyimleyebilirler.

Okula başlayan birey sosyalleşmeye ilk adımlarını atmış olur. Zamanının büyük bir kısmını okulda geçiren bir birey için okul kavramı önemli bir sosyal ortam olarak ele alınabilir. Bahadır'a göre de (1994) uzun yıllarını okul ortamında geçiren ergen için bu ortam yeteneklerini ve becerisini ölçme aynı zamanda test etme imkanı sunar. Kişiliğini şekillendirmede örnek rol modellerle karşılaşma imkanı sunar. Akademik ve entelektüel düşünme becerisinin en iyi kazanıldığı sosyal ortamlardan biri yine okuldur. Ancak okulun uyma etkisini artıran gücü de mevcuttur. Okul, çeteleşmenin oluşması gibi birtakım olumsuz davranışların öğrenildiği bir kurum olarak da öğrencilerin karşısına çıkmaktadır.

Bu noktada da okula aidiyet duygusu kazanmanın bu olumsuz davranışları önleyici bir etkisi olabileceği düşünülebilir. Yapılan çalışmalar incelendiğinde okula aidiyet duygusunun akademik başarı ve motivasyonla pozitif yönde ilişkili olduğu görülmüşken, bu kavramların okulu bırakma kavramı ile de negatif yönde ilişkili olduğu görülmektedir (Finn, 1989; Goodenow, 1993; Osterman, 2000). Duygusal dalgalanmaların yoğunlukta olduğu bu dönemde okul sürecinde öğretmenleri ve arkadaşları tarafindan desteklenme ergeni duygusal açıdan oldukça geliştirir (Capps, 2003).

Aidiyet kavramına değinen Abraham Maslow yaygın olarak bilinen ihtiyaçlar hiyerarşisini ortaya atmıştır. Hiyerarşide bazı ihtiyaçların daha önce doyurulması gerektiği vurgulanır ve bir ihtiyaç doyurulmadan diğerine geçilmez. Beş katmandan oluşan hiyerarşide en alt basamak fizyolojik gereksinimleri oluştururken en üst basamakta da kendini gerçekleştirme ihtiyacı bulunmaktadır. Maslow'un ihtiyaçlar hiyerarşisi teorisine göre, bireyin ergenlik dönemine girmesiyle birlikte kimlik gelişimiyle bağlantılı aidiyet, statü ve üst benlik ihtiyaçları daha çok ön plana çıkar (Kuşat, 2003). Kılıçoğlu'na (2014) göre okula aidiyet duygusu, eğitim ve psikoloji ile bağlantılı olan bir kavramdır. Ait olma, ilgili olma, topluluk duygusu, okul üyeliği, sınıfta olan üyelik, destek ve kabul gibi birçok kavramla tanımlanabilecek bir kavramdır. Finn (1989) okula aidiyet duygusunu öğrencilerin okula karşı bir hassasiyet duygusu hissetmeleri, kendilerini okula bağlı hissetmeleri ve okulun amaçlarına değer vermeleri şeklinde tanımlamaktadır. Okul, öğrencilerin uzun bir zaman dilimince zaman geçirdikleri bir ortamdır. Okul bu kapsamda ayrıca öğrencilere bir gruba dahil olduklarını gösteren sosyal bir kurumdur. $\mathrm{Bu}$ sosyal ortamın üyelerinin birbirleriyle sağlklı iletişim kurabildikleri, okul-sınıf ortamında kendini ifade edebildikleri, bir gruba ait olmanın hissiyatını yaşayabildikleri bir yapıda olması beklenir (Günalan, 2018). Bu bakış açısıyla değerlendirildiğinde okul sadece akademik bilgilerin aktarıldığı bir kurum değil aynı zamanda sosyolojik ve psikolojik ihtiyaçların da giderildiği bir 
ortamdır. Osterman'a (2000) göre okula aidiyet duygusu, mutluluk, hoșnutluk vb. olumlu duygularla ilişkilendirilebilirken dışlanma durumu da kıskançlık, yalnızlık, anksiyete gibi olumsuz duygularla ilişkilendirilmektedir. Okulun bir yaşam alanı olduğu düşünüldügünde öğrencilerin belirtilen olumlu ve olumsuz duyguları ziyadesiyle deneyimleyebilecekleri düşünülebilir. Okula aidiyet duygusu ergenlerin gelişim dönemlerine ait ihtiyaçlarını karşıladığı için onların okula uyumu önemlidir (Özgök, 2013). Ayrıca Arıkan (2015) aidiyet duygusunun oluşabilmesinde bireyin üyesi olduğu grup içindeki kabul edilebilirlik düzeyi ile diğer bireylerle etkileşiminin önemli olduğunu vurgulamıştır. Alaca (2011) da okulda bireylerin aidiyet hislerinin oluşması için kişinin kendine özgü bir egemenlik alanı olması ve ya rahat davranışlar sergileyebileceği bir çevre olması gerektiği üzerinde durmaktadır. Ayrıca okul ikliminin başarı ve güven çerçevesinde olması, öğrenci-öğretmen-veli-idarecilerin birbirleriyle pozitif ilişkileri, öğrencilerin kurdukları arkadaşlıklar, okulun fiziki donanımı, okulda yapılan sosyokültürel faaliyetlerin yeterli sayıda olması, akademik programların öğrencilerin psikososyal gelişimlerine uygunluğu, okulun şiddet öğelerinden arınık bir okul olma özelliği öğrencilerin okullarına ilişkin olarak memnuniyet düzeylerini arttıran faktörler kapsamında ele alınmaktadır. Bu kapsamda, okuluna ilișkin memnuniyet duygusu artan öğrencilerin okula aidiyet duygularının yüksek olacağı düşünülebilir (Özdemir, Sezgin, Şirin, Karip ve Erkan, 2010). Bu bilgilerden hareketle okulun aidiyet hissiyat1 oluşturma yönündeki rolüne ulaşılabilir. Bunu destekler nitelikte Booker (2004) okulların ergenler için aidiyet ve sosyal ilişkileri deneyimlemek adına ilk sırada yer aldığını vurgulamaktadır. Bu bilgilerden yola çıkarak okula aidiyet duygusunun ve okula bağl1lı̆̆ının gerek başarı yönünden gerek de geleceğe bakış açılarında anahtar bir rol oynayacağı düşünülebilir (Altınsoy ve Özyer, 2018).

Okula bağl1lık öğrencilerin okulla ilgili olumlu duygularının yanında okul faaliyetlerine katılmasını da içermektedir (İhtiyaroğlu ve Demir, 2015). Fredricks, Blumenfeld ve Paris (2004) çalışmalarında okul bağlılığını üç boyutta incelemişlerdir. Bunlar; davranışsal, duyuşsal ve bilişsel boyut kapsamında ele alınır. Davranışsal boyut öğrencilerin faaliyetlere katılım düzeyini ifade eder. $\mathrm{Bu}$ bakış açısıyla gözlemlenebilen bir içeriğe sahip olduğu yorumuna gidilebilir. Duyuşsal boyutun okul ortamında bulunan diğer bireylere ilișkin tutumu oluşturduğu ifade edilmektedir. Duyuşsal bağl1lığ1 yüksek olan öğrencilerin okuldaki faaliyetlere karşı pozitif bir tutum sergiledikleri belirtilmektedir. Aynı zamanda ders içinde de ilgili ve hevesli bir görünüm çizerler. Bilişsel bağlılık öğrencilerin özveri ve zihinsel performans göstermeye istekli olmalarını karakterize etmektedir. Zor ve uğraştırıcı konular karşısında gösterilen zihinsel süreçler bilişsel bağlıllğını ifade etmektedir. Öğrencilerin öğrendiklerini niçin ve nasıl yaptıkları konusunda düşüncesel süreç içine girmeleri de bilişsel bağl1lıktır (Arastaman, 2009). Bu kapsamda okul bağlılı̆̆ının bilişsel boyutu yüksek olan öğrencinin "nasıl" ve "niçin" soruları yardımıyla etkili başa çıkma stratejilerini kullandığı düşünülebilir.

Yaşam koşulları göz önüne alındığını stres kavramını ortadan kaldırmanın mümkün olmadığı görünmektedir. Çünkü insan her süreçte zorluklarla karşı karşıya kalabilmekte ve yaşamış olduğu soruna ilişkin bir karar alma aşamasına gelebilmektedir. Bu kapsamda da en iyi yol stresin olumsuz sonuçlarını ortadan kaldırmaktır. Bu süreç ise başa çıkma şeklinde ifade edilebilir. Başa çıkma bireyin olumsuz deneyimlerden koruyan olumlu deneyimlerin pekişmesini sağlayan bir kavram olarak ele alınabilir (Uygur, 2017). Ergenlik dönemi fiziksel, sosyal ve psikolojik açıdan değişimleri içeren bir dönemdir. Ergenler yaşadıkları değişimler karşısında duygusal, davranışsal ve düşüncesel anlamda zorlanmalar yaşayabilirler. $\mathrm{Bu}$ zorlanmalarla mücadele etme boyutuyla ele alındığında ergenlik döneminde etkili başa çıkma stratejilerini kullanmak, stres içeren bu dönemi sağlıklı bir şekilde atlatmalarına yardımcı olabilir. İnsanlar yaşamlarında denge durumlarını, düzenlerini ve içinde bulundukları duruma uyum sağlayabilme sürecini etkileyebilecek içsel ve dışsal birçok uyarıcı ile karş1 karşıya gelirler (Doğan, Sapmaz ve Totan, 2011). Söz konusu uyarıcılar bireyi zorlayabilecek ve sağlanmış olan dengelenme durumunu bozabilecek özelliklere sahip ise birey yeniden uyum sağlama ve denge kurmak için çaba gösterir (Doğan, 2009). Bir başka deyişle, bireyin kendisini fizyolojiksosyolojik-psikolojik yönden zorlayabilecek bir durumla karşılaştığında, zor duruma ilişkin çeşitlilik içeren birçok tepki göstermesi beklenebilir. Bu tepkiler "başa çıkma" olarak değerlendirilebilir. Başa çıkma kelimesinin kökeni Yunanca "kolahos" kelimesinden gelmektedir. Kelimenin anlamına bakıldığında ise karşı karșıya kalmak, karşılamak ve ya çarpışmak şeklindedir (Eryılmaz, 2009). Başa çıkma algılanan bir tehdit karşısında içinde bulunulan kaygıyı yenme olarak tanımlanır ve kaygı verici durumdan kurtulmak için insanlar farklı yöntemler kullanmaktadır (Burger, 2006). Balıkcı'ya (2010) göre başa çıkma bireyin kendisi için stres oluşturan olay veya etkenlere karşı direnmesi bu durumlara 
dayanabilmek amacıyla bilişsel, davranışsal ve duygusal tepkilerin tamamına verilen isimdir. $\mathrm{Bu}$ durumda verilen tepki var olan memnuniyetsizlik yaratan durumdan bir kurtuluş yolu olarak düşünülebilir. Başa çıkma kavramının bu tarz bir durumda önemli bir kavram olarak ön plana çıktığı söylenebilir. Stres verici olaylar ya da etkenlerin olumsuz etkilerini ortadan kaldırmak ya da en aza indirmek için bazı başa çıkma tutumlarını kullanmak evrenseldir (Ağargün, Beşiroğlu, Kuran, Özer ve Kara, 2005).

Stresin birey için ciddi bir tehdit olabileceği düşünüldügünde stresle başa çıkmanın da bir o kadar önemli olduğu görülebilir. İki insan aynı koşullarda farklı tepkiler verebilir. Biri kaygılı ve gerilimliyken diğeri oldukça sakin ve soğukkanlı bir görünüm çizebilir. Dolayısıyla her bireyin kendine özgü bir başa çıkma tarzı geliştirdiği ifade edilebilir (Altıok, 2011). Bireyler; psikolojik, biyolojik ve sosyolojik açıdan dengededir. Bu üç faktörden birinin dengesinin bozulması stresi faktörünü ön plana çıkarır ve bireyler tekrar denge sürecine girmek için tepkiler üretir. Kısacası bireye göre stres, dengenin bozulmasına yönelik yeni bir uyum sağlanmasını gerektiren bir işarettir (Aydoğdu, 2013). Bu bilgiler 1şı̆̆ında başa çıkmanın bir dengelenme ya da yeniden uyum sağlama süreci olduğunu net bir şekilde söylenebilir. Uyum sağlamadaki başarısızlık bireyi birçok yönde etkileyebilir. Başa çıkma stilleri ilk olarak Freud tarafından psikodinamik kuram çerçevesinde ele alınmıştır. Freud'un bakış açısına göre başa çıkma davranışları, egonun kendini ve bütünlüğünü koruması amacıyla bireyin kullandığı bastırma ve inkar gibi davranışsal kalıplar biçimleri temelinde gerçekleşmektedir (Geçtan, 1999). İlerleyen yıllarda başa çıkma fenemenolojik bakış açısı kazanmıştır ve Lazarus ve Folkman (1984) başa çıkma stillerini içsel ya da dışsal faktörlere bağlı stres durumlarını yönetebilmek için oluşturulan bilişsel ve davranışsal çabalara yönelik planlar şeklinde ele alınmıştır (Uygur, 2017).

Literatür incelendiğinde başa çıkma stratejileri ile ilgili birçok farklı kategori oluşturulduğunu görmekteyiz. Örneğin yaklaşan-problem odaklı, kaçınan-duygu odaklı (Lazarus ve Folkman, 1984), birincil-ikincil kontrol ve geri çekilme (Connor-Smith, Compas, Wadsworth, Thomsen ve Saltzman, 2000), aktif, kaçınan, olumsuz (Sprinto, Stark ve Tyc, 1994), aktif, geri çekilen, karşı çıkan (Holen, Lervag, Waaktaata ve Ystgaard, 2012) gibi farklı kategorilerde değerlendirilmektedir. Çocuk ve ergenler için başa çıkma stratejilerinin ölçümünde sıklıkla kullanılan ölçekler incelendiğinde (Sprinto, Stark ve Williams, 1988) tarafından geliştirilen Çocuk ve Ergenler için Başa Çıkma (Kidcope) Ölçeği görülmektedir. Ölçeğin yaygın olarak kullanılmasının gerekçesi olarak çocuk ve ergen gruplarında başa çıkma stratejilerinin ölçülmesinde az sayıda ölçme aracı geliştirilmesi ve yaygın olarak üniversite çağı ve üzerindeki yaş gruplarının hedef kitle olarak ele alınmasıdır (Bedel, Işık ve Hamarta, 2014). Sprinto, Stark ve Wiiliams, 1998 tarafından geliştirilen ölçek üç boyutta ele alınmaktadır. Bunlar; aktif, kaçınan ve olumsuz olarak kategorilendirilmiştir. Aktif başa çıkma stratejisi yapıcıdır ve işlevsel bir başa çıkma stratejisidir. Kaçınan başa çıkma stratejisi problemle yüzleşmek yerine ondan uzaklaşma gibi işlevsel olmayan davranışları içinde barındırır. Olumsuz başa çıkma stratejisinde ise birey çevreyi tehdit olarak algılar, sorunu çözemeyeceğine inanır, kendini ve çevresini suçlar ve bu durumlara ek olarak etrafına zarar verici davranışlar içine girer (Bedel ve Ulubey, 2015).

Başa çıkma becerisi hayatın ilk yıllarından itibaren dikkate alınması ve desteklenmesi gereken bir konudur. Bu durumun etkileri ise ömür boyu devam etmektedir (Eroğlu, 2001). Ergenlik döneminde yaşanan fiziksel, psikolojik ve sosyolojik birtakım değişimler ergenler için stres yaratan etmenlerdir. Ergenliğin başlangıç döneminde ergenler fiziksel, duygusal ve psikolojik açıdan birçok stres yaratan etmenler karşı karşıyadır ancak henüz işlevsel ve yeterli başa çıkma becerilerine sahip değillerdir. Türküm, Kızıltaş ve Sarıyer'e (2004) göre de ergen bireyler karşılaştıkları sorunlarla aktif başa çıkma gibi işlevsel becerileri seçebildikleri gibi işlevsel olmayan başa çıkma stratejilerini seçtikleri de saptanmıştır. Ergenlik döneminin ilerleyen yıllarında deneyim kazanan ergen başa çıkma becerileri konusunda kendisini geliştirir. Bu süreçte yetişkinler rol model alınır ve yetişkinlerin etkisi önemlidir. Okul öncesi dönem ve ilkokul döneminde rol model alma yöntemleri ile sorun çözme becerileri geliştirilirken duygusal anlamda başa çıkma, yaşanan duygulara ilişkin farkındalık kazanarak duyguları yönetme faaliyeti çocukluğun bitimine ve ergenliğin ilk dönemlerinde gelişme gösterir (Compas, 1998). Eryılmaz'a (2009) göre de uyum sağlamadaki başarısızlık çocukluk ve ergenlikte sosyal, bilişsel ve psikolojik gelişimi olumuz yönde etkiler. Bu nedenledir ki ergenlik döneminde başa çıkma kavramı oldukça önemlidir. Yapılan araştırmalarda ergenlerin başa çıkma becerilerinin düşük olmasından kaynaklı olarak birçok psikososyal sorun yaşadığını ifade etmektedir. Düşük akademik başarı gösterme, yeme bozuklukları, kaygı, depresyon, şiddet gibi sorunlar bunlara örnek gösterilebilir. Baş etme stratejilerinin kullanımı ergenlik döneminde daha da fazla önem arz etmektedir. Bu duruma gerekçe 
olarak da ergenlerin riskli davranışlar geliştirme olasılığının yüksek olmasından kaynaklanmaktadır. Çünkü bu dönemde ergen başa çıkma stratejilerini tam olarak geliştirememiştir. Dolayısıyla da riskli davranışlar istenmeyen durumlarla sonuçlanabilir. Ancak eğitim ve deneyim kazanma yöntemleriyle ergen sağlıklı bir başa çıkma becerisi geliştirebilir (Öngen, 2002). Kurt'a (2013) göre de yaşamda stres yaratan durumlarda her birey gibi ergenler de farklı tepkiler vermektedir. Stresin psikolojik yansımalarının ruh sağlığımız üzerinde olumsuz etkilere sebebiyet verdiğini düşündüğümüzde dahi etkili başa çıkma stratejilerini kullanan ergenlerin bu etkiyi azaltabileceği ve etkili bir şekilde başa çıkabileceği söylenebilir Masten'e (2001) göre de ergenlerin stresli yaşam olaylarına karşı verdiği tepkiler aynı değildir. Bazı ergenlerin stres kaynakları psikolojik ya da fiziksel rahatlıkla ilişkili olmadığı görülmektedir. Buna karşın bazı ergenler ağır olumsuz olaylar karşısında yılmazlık gösterebilirler. Bu tarz bir durumda kötü yaşam olaylarıyla karşı karşıya kalan ergenin etkili başa çıkma stratejileri kullanabildiği seçenekler arasında olabilir. Okula aidiyet kavramı Türkiye'de liseli ergen grubunda Arastaman (2006)'dan sonra araştırılmaya başlayan bir konu olmuştur. Okul öncesi ilkokul ve ortaokul ve üniversite grubuyla çalışmalara literatürde sık karşılaşıldığ 1 görülmektedir. Ergenlerin okula aidiyetleri ve başa çıkma stratejileri arasındaki ilişkinin ise bir çalışmaya konu olmadığ görülmüştür. Ayrıca üç farklı okul türünden (Meslek Lisesi, Anadolu Lisesi, Fen Lisesi) öğrencileri çalışma grubu olarak ele alması yapılan çalışmanın orijinal olduğunu ortaya koymaktadır.

Araştırmanın genel amacı ergenlerin okula aidiyet duyguları ve başa çıkma stratejileri arasındaki ilişkiyi incelemektir. Ayrıca cinsiyet, sınıf düzeyi, okul türü, algılanan akademik başarı ve lise seçim süreçleri de incelenmiştir.

Yapılan çalışmanın ortaöğretim kurumlarında görev yapan öğretmenlere, idarecilere ve özellikle de psikolojik danışmanlara okula aidiyet konusunu ele alması ile okul devamsızlığını ve terkini önleme, 1lımlı okul iklimi oluşturma, akademik motivasyon, etkili başa çıkma stratejilerinin uygulanmasıyla davranışsal sorunların ve disiplin problemlerinin azalması vb. durumlarda yol gösterici olması niteliğiyle yararlı olacağı düşünülmektedir.

\section{YÖNTEM}

\section{Araştırmanın Modeli}

Araştırma ergenlerin okula aidiyet duyguları ve başa çıkma stratejilerini incelemek amacıyla, nicel veri toplama tekniklerinin kullanıldığı tarama modelinde gerçekleştirilmiştir. Tarama modeli geçmişte ya da günümüzde olan bir durumu değiştirmeden ortaya koyan bir araştırma yaklaşımıdır. Geniş gruplar üzerinde yürütülen tarama modeli bireylerin, bir olgu veya olay ile ilgili tutumlarının ele alındığ 1 araştırmalardır. (Karasar, 2008).

\section{Çalışma Grubu/ Evren- Örneklem}

Araştırmanın evrenini 2018-2019 eğitim-öğretim yılında Kırklareli ilinin Milli Eğitim Bakanlığı'na bağlı ortaöğretim kurumlarında öğrenim görmekte olan öğrenciler oluşturmaktadır. Araştırmanın çalışma grubunu ise gönüllülük ilkesine dayalı olarak Kırklareli ilinin Lüleburgaz ilçesinde Milli Eğitim Bakanlığı'na bağlı Mesleki ve Teknik Anadolu Lisesi'nde öğrenim görmekte olan 394 öğrenci, Anadolu Lisesi’nde öğrenim görmekte olan 515 öğrenci ve Fen Lisesi’nde öğrenim görmekte olan 305 öğrenci olmak üzere üç farklı türdeki ortaöğretim kurumundaki toplam 1214 öğrenci oluşturmaktadır. 
Tablo 1.

Çalışma grubuna ait demografik bilgiler

\begin{tabular}{llll}
\hline & & Frekans & Yüzde \\
\hline \multirow{3}{*}{ Cinsiyet } & Kız & 738 & 60.8 \\
& Erkek & 476 & 39.2 \\
& Toplam & 1214 & 100.0 \\
\hline \multirow{4}{*}{ Sinıf } & 9. sinıf & 349 & 28.7 \\
& 10. sinıf & 310 & 25.5 \\
& 11. sinıf & 255 & 21.0 \\
& 12. sinff & 300 & 24.7 \\
\multirow{3}{*}{ Okul Türü } & Toplam & 1214 & 100.0 \\
& Fen Lisesi & 305 & 25.1 \\
& Anadolu Lisesi & 515 & 42.4 \\
& Meslek Lisesi & 394 & 32.5 \\
& Toplam & 1214 & 100.0 \\
\hline
\end{tabular}

Araştırmaya dahil edilen ergenlerin \%60.8'i kız ve \%39.2'si erkek; \%28.7'si 9. sınıfta, \%25.5'i 10. sinıfta, \%21'i 11. sinıfta ve \%14.7'si 12. sınıfta öğrenim görmektedir. Ayrıca öğrencilerin \%21.1'i Fen Lisesinde, \%42.4'ü Anadolu Lisesinde ve \%32.5'i Meslek Lisesinde öğrenim görmektedir.

\section{Veri Toplama Aracı}

Çalışmada Okula Aidiyet Duygusu Ölçeği ve Ergenler için Başa Çıkma Stratejileri Ölçeği kullanılmış olup gerekli izinler yazarlardan alınmıştır.

Goodenow'un (1993) geliştirmiş olduğu Okula Aidiyet Duygusu Ölçeği’nin Türkçe’ye uyarlaması Sarı (2011) tarafından yapılmıştır. Öğrencilerin okula yönelik kişisel değerlendirmelerini içeren (Bu okulda olmaktan gurur duyuyorum gibi) toplamda 18 maddeden oluşan likert tipinde (1. Hiç doğru değil, 2. Doğru değil, 3. Karasızım, 4. Doğru, 5. Tamamen doğru) bir ölçme aracidır.

Ölçeğin faktör analizleri Sarı (2011) tarafından yapılmıştır. Maddelerin iki bileșende toplandıkları görülmekle birlikte toplam varyansın \%28.90 ve \%9.59'una karş1lı geldikleri saptanmıștır. Okula aidiyet duygusu birinci faktör olarak ele alınmıștır ve 13 olumlu maddeyi içermektedir. Reddedilmişlik duygusu da ikinci faktör olarak ele alınmıştır ve 5 olumsuz maddeyi $(3,6,9,12,16)$ içermektedir. Maddelere ait faktör yükleri okula aidiyet duygusunda 0.44 ile .66 arasında; reddedilmişlik duygusunda 0.46 ile 0.75 arasındadır. Okula aidiyet duygusuna ilişkin alfa iç tutarlılık katsayısının .84; reddedilmişlik duygusuna ilişkin alfa iç tutarlılık katsayısının .78 olduğu saptanmıştır. Olumsuz maddeler çevrilip puanlandığında iki ölçeğe ait Cronbach alfa iç tutarlık katsayısı .84 olarak saptanmıştır. Madde-toplam puan korelasyonları .31-.61 arasındadır. Alt ve üst \%27'lik gruplar için yapılan $\mathrm{t}$ testi sonucunda da tüm maddelerin grupları anlamlı bir şekilde ayırt edebildiği saptanmıştır $(\mathrm{p}<.001)$.

Sprinto ve arkadaşları (1988) tarafından geliştirilen EBÇÖ; Bedel, Işık ve Hamarta (2014) tarafından Türkçe'ye uyarlanmıştır. Ölçek toplamda 11 maddeden ve üç alt boyuttan oluşmaktadır. Ölçek aktif başa çıkma, kaçınan başa çıkma ve olumsuz başa çıkma boyutlarını içermektedir. Hiçbir Zaman(0), Ara Sıra (1), Çoğu Zaman (2), Her Zaman (3) üzerinden derecelendirmeler yapılmaktadır. "Kendi başıma kalarak sorunumu çözmeye çalışırım" ölçekte yer alan örnek bir madde olarak gösterilebilir. Alt ölçeklerden alınabilecek puanlar aktif ve kaçinan başa çıkma için 0-12, olumsuz başa çıkma için 0-9 puan arasında değişebilir. Ölçeğin iç tutarlılık güvenirlik katsayısı aktif başa çıkma için .72 , kaçınan başa çıkma için .70 ve olumsuz başa çıkma için .65 bulunmuştur. Test-tekrar test değerlendirmesi üç hafta sonra yapılmıştır ve güvenirlik katsayısı aktif başa çıkma için $r=.66$, kaçınan başa çıkma için $r=.61$ ve olumsuz başa çıkma için $r=.76$ elde edilmiştir. Bu sonuçlar analizleri yapılan EBÇÖ'nün Türkçe formunun ergenlik dönemindeki öğrencilerin başa çıkma yaklaşımlarını değerlendirebilecek geçerli ve güvenilir bir ölçme aracı olduğunu göstermektedir (Bedel, Işık ve Hamarta, 2014). 


\section{Verilerin Toplanması ve Analizi}

Elde edilen verilerin normal dağılıma uyup uymadığı saptamak amaciyla Kolmogorov-Smirnov ve Shapiro Wilk normallik testleri uygulanmıștır. Ölçeklerden elde edilen verilerin varsayımları sağlamadığ 1 durumlarda kullanılan parametrik olmayan yöntemlerden Kruskal Wallis Testi; varyans analizlerinde anlamlı değerler çıkması durumunda bu farklılığın hangi boyutlar arasından kaynaklandığını belirlemek için Mann-Whitney U Testi kullanılmıştır. Okula aidiyet duygusu, başa çıkma stratejileri ve alt boyutları arasındaki ilişkisel değerlere bakmak için verilerin normal dağılmaması nedeni ile Spearman Sıra Farkları korelasyon analizi kullanılmıştır.

\section{BULGULAR}

Araştırmanın genel amacı ergenlerin okula aidiyet duyguları ve başa çıkma stratejileri arasındaki ilişkiyi incelemektir. Bununla birlikte çalışmada yer alan ergenlerin çeşitli değişkenlere göre (cinsiyet, okul türü, sınıf düzeyi vb.) okula aidiyet duyguları ve başa çıkma stratejileri de inceleme konusu yapılmıştır. Elde edilen verilerin sonucunda elde edilen bulgular ilgili bölümde sunulmaktadır.

Ergenlerin okula aidiyet duygusu puanları ile başa çıkma stratejileri puanları arasındaki ilişki olup olmadığını test etmek için yapılan Spearman Sıra Farkları korelasyon analizi sonuçları tablo 2'de verilmiştir.

Tablo 2.

Spearman sıra farkları korelasyon analizi sonuçları

\begin{tabular}{lllll}
\hline & & Aktif & Kaçınan & Olumsuz \\
& Korelasyon Katsayısı & Başa Çıkma & Başa Çıma & Başa Çıma \\
\hline \multirow{2}{*}{$\begin{array}{l}\text { Okula Aidiyet Duygusu Boyutu } \\
\end{array}$} & $\mathrm{P}$ & .351 & -.107 & -.172 \\
& $\mathrm{~N}$ & .000 & .000 & .000 \\
& $\mathrm{~N}$ & 1214 & 1214 & 1214 \\
$\begin{array}{l}\text { Reddedilmişlik Duygusu } \\
\text { Boyutu }\end{array}$ & $\mathrm{P}$ & -.234 & .205 & .210 \\
& $\mathrm{~N}$ & .000 & .000 & .000 \\
& $\mathrm{~N}$ & 1214 & 1214 & 1214 \\
\hline
\end{tabular}

Tablo 2'ye göre ergenlerin okula aidiyet duygusu boyutu ile aktif başa çıkma boyutu arasında orta düzeyde pozitif yönde istatistiksel olarak anlamlı bir ilişki bulunmuştur $(\mathrm{p}<0.01)$. Ergenlerin okula aidiyet duygusu boyutu ile kaçınan başa çıkma ve olumsuz başa çıkma boyutları arasında negatif yönde istatistiksel olarak anlamlı ancak düşük düzeyde bir ilişki bulunmaktadır $(\mathrm{p}<0.01)$. Ergenlerin reddedilmişlik duygusu boyutu ile aktif başa çıkma boyutu arasında negatif yönde istatistiksel olarak anlamlı ancak düşük düzeyde bir ilişki bulunmuştur $(p<0.01)$. Ergenlerin reddedilmişlik duygusu boyutu ile kaçınan başa çıkma ve olumsuz başa çıkma boyutları arasında pozitif yönde istatistiksel olarak anlamlı ancak düşük düzeyde bir ilişki bulunmaktadır ( $\mathrm{p}<0.01)$.

Ergenlerin okula aidiyet duygusu boyutu puanları ve reddedilmişlik duygusu boyutu puanlarının cinsiyete göre farklılık gösterip göstermediğini belirlemek için yapılan Mann-Whitney U testi analizi sonuçları Tablo 3 'te verilmiştir. 
Tablo 3

Cinsiyete göre Mann Whitney U testi sonuçları

\begin{tabular}{lllllll}
\hline & Cinsiyet & N & Sira Ort. & Sira Top. & U & P \\
\hline \multirow{2}{*}{$\begin{array}{l}\text { Okula Aidiyet Duygusu } \\
\text { Boyutu }\end{array}$} & K1z & 738 & 571.70 & 421913.50 & 149222.500 & .000 \\
& Erkek & 476 & 663.01 & 315591.50 & & \\
& Toplam & 1214 & & & & \\
\hline \multirow{2}{*}{$\begin{array}{l}\text { Reddedilmişlik Duygusu } \\
\text { Boyutu }\end{array}$} & K1z & 738 & 615.56 & 454285.50 & 169693.500 & .317 \\
& Erkek & 476 & 595.00 & 283219.50 & & \\
& Toplam & 1214 & & & & \\
\hline
\end{tabular}

Tablo 3'e göre ergenlerin okula aidiyet duygusu puanları cinsiyete göre istatistiksel olarak anlamlı farklılık göstermektedir $(\mathrm{p}<0.05)$. Erkek ergenlerin okula aidiyet duygusu boyutundan elde ettikleri puanların kız ergenlerin puanlarından manidar olarak daha yüksek olduğu görülmüştür. Ergenlerin reddedilmişlik duygusu boyutu puanları ise cinsiyete göre istatistiksel olarak anlamlı farkl111k göstermemektedir ( $\mathrm{p}>0.05)$.

Ergenlerin okula aidiyet duygusu boyutu puanları ve reddedilmişlik duygusu boyutu puanlarının sınıf düzeyine göre farklılık gösterip göstermediğini belirlemek için yapılan Kruskal Wallis testi analizi sonuçları tablo 4'te verilmiştir.

Tablo 4.

Sınıf düzeyine göre Kruskal Wallis testi sonuçları

\begin{tabular}{|c|c|c|c|c|c|c|c|}
\hline & Sinif & $\mathrm{N}$ & Sira Ort. & Ki-kare & $\mathrm{sd}$ & $\mathrm{p}$ & Farkl111k \\
\hline \multirow{5}{*}{$\begin{array}{l}\text { Okula Aidiyet Duygusu } \\
\text { Boyutu }\end{array}$} & 9. Sinıf & 349 & 709.28 & 46.275 & 3 & .000 & 9. $\sin ı f>10$. Sinif \\
\hline & 10. Sinif & 310 & 596.72 & & & & 9. $\sin 1 f>11$. Sinif \\
\hline & 11. Sinif & 255 & 568.16 & & & & 9. $\sin 1 f>12 . \operatorname{Sin} 1 f$ \\
\hline & 12. Sinif & 300 & 533.68 & & & & 10. $\sin 1 f>12$. Sinif \\
\hline & Toplam & 1214 & & & & & \\
\hline \multirow{5}{*}{$\begin{array}{l}\text { Reddedilmişlik Duygusu } \\
\text { Boyutu }\end{array}$} & 9. Sinif & 349 & 485.51 & 61.417 & 3 & .000 & 9. $\sin ı f<10$. Sinif \\
\hline & 10. Sinif & 310 & 636.03 & & & & 9. $\sin 1 f<11 . \operatorname{Sin} 1 f$ \\
\hline & 11. Sinif & 255 & 674.33 & & & & 9. $\sin 1 f<12 . \operatorname{Sin} 1 f$ \\
\hline & 12. Sinif & 300 & 663.13 & & & & \\
\hline & Toplam & 1214 & & & & & \\
\hline
\end{tabular}

Tablo 4 incelendiğinde ergenlerin okula aidiyet duygusu puanları, ergenlerin sınıf düzeyine göre istatistiksel olarak anlamlı şekilde farklılaştı̆̆ görülmektedir $(p<0.05)$. Bu farklılık 9. Sınıf öğrencileri ile üst sınıftaki ergenler arasında ve 10. Sinıftaki ergenlerin puanları ile 12. Sinıftaki ergenler arasında olup, ergenlerin sınıf düzeyleri arttıkça okula aidiyet duygusu boyutu puanları azalmaktadır. Ergenlerin reddedilmişlik duygusu boyutu puanları, ergenlerin sınıf düzeyine göre istatistiksel olarak anlamlı şekilde farklılık göstermektedir $(\mathrm{p}<0.05)$. Bu farklılık 9. Sınıftaki ergenler ile üst sınıftaki ergenler arasında olup ergenlerin sınıf düzeyleri arttıkça reddedilmişlik duygusu boyutu puanlarının arttı̆̆ bulunmuştur.

Öğrencilerin okula aidiyet duygusu boyutu puanları ve reddedilmişlik duygusu boyutu puanlarının okul türüne göre farklılık gösterip göstermediğini belirlemek için yapılan Kruskal Wallis testi analizi sonuçları tablo 5'te verilmiştir. 
Tablo 5.

Okul türüne göre Kruskal Wallis testi sonuçları

\begin{tabular}{|c|c|c|c|c|c|c|}
\hline & Okul türü & $\mathrm{N}$ & Sira Ort. & Ki-kare & $\mathrm{Sd} \mathrm{p}$ & Farklılık \\
\hline \multirow{4}{*}{$\begin{array}{l}\text { Okula } \\
\text { Aidiyet Duygusu } \\
\text { Boyutu }\end{array}$} & Fen Lisesi & 305 & 743.34 & 68.272 & .000 & Fen Lisesi > Anadolu Lisesi \\
\hline & Anadolu Lisesi & 515 & 588.89 & & & Fen Lisesi > Meslek Lisesi \\
\hline & Meslek Lisesi & 394 & 526.66 & & & Anadolu Lisesi>Meslek Lisesi \\
\hline & Toplam & 1214 & & & & \\
\hline \multirow{4}{*}{$\begin{array}{l}\text { Reddedilmişlik } \\
\text { Duygusu Boyutu }\end{array}$} & Fen Lisesi & 305 & 532.30 & 33.382 & 2.000 & Fen Lisesi<Anadolu Lisesi \\
\hline & Anadolu Lisesi & 515 & 594.03 & & & Fen Lisesi<Meslek Lisesi \\
\hline & Meslek Lisesi & 394 & 683.33 & & & Anadolu Lisesi<Meslek Lisesi \\
\hline & Toplam & 1214 & & & & \\
\hline
\end{tabular}

Okula aidiyet duygusu boyutu ve reddedilmişlik duygusu boyutu için tüm okul türleri arasındaki farklılık istatistiksel olarak anlamlıdır. En yüksek okula aidiyet duygusu puanı Fen Lisesi'ndeki ergenlere ait iken, en düşük okula aidiyet duygusu puanları Meslek Lisesi'ndeki ergenlere aittir. En yüksek reddedilmişlik duygusu puanı Meslek Lisesi'ndeki ergenlere ait iken, en düşük reddedilmişlik duygusu puanları Fen Lisesi'ndeki ergenlere aittir.

Ergenlerin okula aidiyet duygusu boyutu puanları ve reddedilmişlik duygusu boyutu puanlarının algılanan başarı düzeyine göre farklılık gösterip göstermediğini belirlemek için yapılan Kruskal Wallis testi analizi sonuçları tablo 6'da verilmiştir.

Tablo 6.

Algılanan başarı düzeyine göre Kruskal Wallis testi sonuçları

\begin{tabular}{llllllll}
\hline & Başarı & N & Sira Ort. & Ki-kare & sd & p & Farklılık \\
& Düzeyi & & & & & \\
& Düşük & 68 & 446.58 & 53.307 & 2 & .000 & Düşük<Orta \\
Okula Aidiyet & Orta & 808 & 575.72 & & & & Düşük< $<$ Ÿksek \\
Duygusu Boyutu & Yüksek & 338 & 715.84 & & & & Orta $<$ Yüksek \\
& Toplam & 1214 & & & & & \\
\hline \multirow{3}{*}{ Reddedilmişlik } & Düşük & 68 & 778.26 & 27.708 & 2 & .000 & Düşük $>$ Orta \\
Duygusu Boyutu & Orta & 808 & 619.06 & & & & Düşük $>$ Yüksek \\
& Yüksek & 338 & 545.51 & & & & Orta $>$ Yüksek \\
& Toplam & 1214 & & & & & \\
\hline
\end{tabular}

Tablo 6'ya göre ergenlerin okula aidiyet duygusu puanları ve reddedilmişlik duygusu puanları algılanan başarı düzeyine göre istatistiksel olarak anlamlı farklılık göstermektedir $(\mathrm{p}<0.05)$. Okula aidiyet duygusu boyutu ve reddedilmişlik duygusu boyutu için algılanan başarı düzeylerinin tümü arasındaki farklılık istatistiksel olarak anlamlıdır. En yüksek okula aidiyet duygusu puanı başarı düzeyini yüksek olarak algılayan ergenlere ait iken, en düşük okula aidiyet duygusu puanları başarı düzeyini düşük olarak algılayan ergenlere aittir. En yüksek reddedilmişlik duygusu puanı başarı düzeyini düşük olarak algılayan ergenlere ait iken, en düşük reddedilmişlik duygusu puanları başarı düzeyini yüksek olarak algılayan ergenlere aittir.

Ergenlerin okula aidiyet duygusu boyutu puanları ve reddedilmişlik duygusu boyutu puanlarının lise seçim sürecine göre farklılık gösterip göstermediğini belirlemek için yapılan Kruskal Wallis testi analizi sonuçları tablo 7'de verilmiştir. 
Tablo 7.

Lise seçim sürecine göre kruskal wallis testi sonuçları

\begin{tabular}{llllllll}
\hline & Seçim Süreci & $\mathrm{N}$ & Sira Ort. & Ki-kare & sd & p & Farklılık \\
\hline & Aile & 57 & 423.61 & 58.843 & 2 & .000 & Aile < Kendisi \\
& Kendisi & 351 & 644.48 & & & Aile <Aile ve kendisi \\
Okula Aidiyet & Aile ve kendisi & 456 & 672.06 & & & Kendisi <Puan \\
Duygusu Boyutu & Puan & 350 & 516.24 & & & Aile ve kendisi <Puan \\
& Toplam & 1214 & & & & \\
\hline & Aile & 57 & 836.69 & 89.641 & 2 & .000 Aile > Kendisi \\
& Kendisi & 351 & 557.95 & & & Aile > Aile ve kendisi \\
Reddedilmişlik & Aile ve kendisi & 456 & 530.72 & & & Kendisi > Puan \\
& Puangusu Boyutu & 350 & 719.90 & & & Aile ve kendisi > Puan \\
& Toplam & 1214 & & & & \\
\hline
\end{tabular}

Tablo 7 incelendiğinde ergenlerin okula aidiyet duygusu boyutu puanları ve reddedilmişlik duygusu boyutu puanları lise seçim sürecine göre istatistiksel olarak anlamlı farklılık göstermektedir $(\mathrm{p}<0.05)$. Aile isteğine göre okul seçimi yapanlar ile kendi isteğine göre okul seçimi yapanlar arasında anlamlı farklılık bulunmaktadır, bu farklılığa göre kendi isteğine göre okul seçenlerin okula aidiyet duygusu boyutu puanı istatistiksel olarak daha yüksek, aile isteğine göre okul seçenlerin reddedilmişlik duygusu boyutu puanı istatistiksel olarak daha yüksektir. Sadece aile isteğine göre okul seçenler ile aile ve kendi isteğine göre okul seçimi yapanlar arasında anlamlı farklılık bulunmaktadır. Bu farklılığa göre aile ve kendi isteğine göre okul seçenlerin okula aidiyet duygusu boyutu puanı istatistiksel olarak daha yüksek, sadece aile isteğine göre okul seçenlerin reddedilmişlik duygusu boyutu puanı istatistiksel olarak daha yüksektir. Kendi isteğine göre okul seçenler ile puana göre okul seçimi yapanlar arasında anlamlı farklılık bulunmaktadır. Bu farklılığa göre kendi isteğine göre okul seçenlerin okula aidiyet duygusu boyutu puanı istatistiksel olarak daha yüksek, puana göre okul seçenlerin reddedilmişlik duygusu boyutu puanı istatistiksel olarak daha yüksektir. Aile ve kendi isteğine göre okul seçenler ile puana göre okul seçimi yapanlar arasında anlamlı farklılık bulunmaktadır, bu farklılığa göre aile ve kendi isteğine göre okul seçenlerin okula aidiyet duygusu boyutu puanı istatistiksel olarak daha yüksek, puana göre okul seçenlerin reddedilmişlik duygusu boyutu puanı istatistiksel olarak daha yüksektir.

Ergenlerin aktif başa çıkma, kaçınan başa çıkma ve olumsuz başa çıkma boyutu puanlarının cinsiyete göre farklılık gösterip göstermediğini belirlemek için yapılan Mann-Whitney U testi analizi sonuçları tablo 8'de verilmiştir.

Tablo 8.

Cinsiyete göre Mann-Whitney U testi sonuçları

\begin{tabular}{|c|c|c|c|c|c|c|}
\hline & Cinsiyet & $\mathrm{N}$ & Sira Ort. & Sira Top. & $\mathrm{U}$ & $\mathrm{P}$ \\
\hline \multirow{3}{*}{ Aktif Başa Çıkma } & $\mathrm{K} 1 \mathrm{z}$ & 738 & 593.61 & 438081.50 & 165390.500 & .083 \\
\hline & Erkek & 476 & 629.04 & 299423.50 & & \\
\hline & Toplam & 1214 & & & & \\
\hline \multirow{3}{*}{ Kaçınan Başa Çıkma } & $\mathrm{K} 1 \mathrm{Z}$ & 738 & 612.36 & 451923.50 & 172055.500 & .543 \\
\hline & Erkek & 476 & 599.96 & 285581.50 & & \\
\hline & Toplam & 1214 & & & & \\
\hline \multirow{2}{*}{ Olumsuz Başa Çıkma } & $\mathrm{K} 1 \mathrm{z}$ & 738 & 622.47 & 459383.00 & 164596.000 & .060 \\
\hline & Erkek & 476 & 584.29 & 278122.00 & & \\
\hline
\end{tabular}


Tablo 8'e göre ergenlerin aktif başa çıkma, kaçınan başa çıkma ve olumsuz başa çıkma boyutları puanları cinsiyete göre istatistiksel olarak anlamlı farklılık göstermemektedir ( $p>0.05)$.

Ergenlerin aktif başa çıkma, kaçınan başa çıkma ve olumsuz başa çıkma boyutu puanlarının sınıf düzeyine göre farklılık gösterip göstermediğini belirlemek için yapılan Kruskal Wallis testi analizi sonuçları tablo 9'da verilmiştir.

Tablo 9.

Sinıf düzeyine göre Kruskal Wallis testi sonuçları

\begin{tabular}{llllllll}
\hline & Sinıf & N & Sira Ort. & Ki-kare & sd & p & Farklılık \\
\hline Aktif Başa Çıkma & 9. Sınıf & 349 & 633.44 & 5.869 & 3 & .118 & \\
& 10. Sinıf & 310 & 624.23 & & & & \\
& 11. Sınıf & 255 & 588.92 & & & & \\
& 12. Sınıf & 300 & 575.83 & & & & \\
& Toplam & 1214 & & & & & \\
\hline Kaçınan Başa Çıkma & 9. Sinıf & 349 & 583.46 & 9.734 & 3 & .021 & 9. Sinıf $<$ 10. Sinıf \\
& 10. Sinıf & 310 & 648.34 & & & & 10. Sinıf $>$ 12. Sınıf \\
& 11. Sınıf & 255 & 629.67 & & & & \\
& 12. Sınıf & 300 & 574.42 & & & & \\
& Toplam & 1214 & & & & & \\
\hline Olumsuz Başa Çıkma & 9. Sinıf & 349 & 580.02 & 7.685 & 3 & .053 & \\
& 10. Sinıf & 310 & 631.36 & & & & \\
& 11. Sinıf & 255 & 642.95 & & & & \\
12. Sınıf & 300 & 584.67 & & & & \\
& Toplam & 1214 & & & & & \\
\hline
\end{tabular}

Tablo 9 incelendiğinde ergenlerin kaçınan başa çıkma boyutu puanlarının, ergenlerin sınıf düzeyine göre istatistiksel olarak anlamlı şekilde farklılaştı̆̆ görülmektedir $(\mathrm{p}<0.05)$. Bu farklılık 10. Sinıftaki ergenler ile 9. Sınıf ve 12. Sınıftaki ergenler arasında olup, 10. Sınıftaki ergenlerin kaçınan başa çıkma boyutu puanları 9. Sınıf ve 12. Sınıftaki ergenlerin kaçınan başa çıkma boyutu puanlarından istatistiksel olarak daha yüksektir. Ergenlerin aktif başa çıkma ve olumsuz başa çıkma boyutu puanları, öğrencilerin sınıf düzeyine göre istatistiksel olarak anlamlı şekilde farklılık göstermemektedir ( $p>0.05)$.

Ergenlerin aktif başa çıkma, kaçınan başa çıkma ve olumsuz başa çıkma boyutu puanlarının okul türüne göre farkl1lık gösterip göstermediğini belirlemek için yapılan Kruskal Wallis testi analizi sonuçları tablo 10'da verilmiştir.

Tablo 10.

Okul türüne göre Kruskal Wallis testi sonuçları

\begin{tabular}{lccccccc}
\hline & Okul türü & $\mathrm{N}$ & Sira Ort. & Ki-kare & sd & $\mathrm{p}$ & Farklılık \\
\hline Aktif Başa & Fen L. & 305 & 649.95 & 11.020 & 2 & .004 & Fen L.>Meslek L. \\
Çıkma & Anadolu L. & 515 & 615.73 & & & & Anadolu L.>Meslek L. \\
& Meslek L. & 394 & 563.88 & & & & \\
& Toplam & 1214 & & & & & \\
\hline Kaçınan & Fen L. & 305 & 577.74 & 6.254 & 2 & .044 & Fen L.<Anadolu L. \\
Başa & Anadolu L. & 515 & 635.66 & & & & \\
Çıkma & Meslek L. & 394 & 593.74 & & & & \\
& Toplam & 1214 & & & & & \\
\hline & Fen L. & 305 & 575.12 & 5.784 & 2 & .055 &
\end{tabular}


Tablo 10.

Okul türüne göre Kruskal Wallis testi sonuçları

\begin{tabular}{lccccccc}
\hline & Okul türü & $\mathrm{N}$ & Sira Ort. & Ki-kare & $\mathrm{sd}$ & $\mathrm{p}$ & Farklılık \\
\hline Aktif Başa & Fen L. & 305 & 649.95 & 11.020 & 2 & .004 & Fen L.>Meslek L. \\
Çıkma & Anadolu L. & 515 & 615.73 & & & & Anadolu L.>Meslek L. \\
& Meslek L. & 394 & 563.88 & & & & \\
& Toplam & 1214 & & & & & \\
\hline Kaçınan & Fen L. & 305 & 577.74 & 6.254 & 2 & .044 & Fen L.<Anadolu L. \\
Başa & Anadolu L. & 515 & 635.66 & & & & \\
Çkma & Meslek L. & 394 & 593.74 & & & & \\
& Toplam & 1214 & & & & & \\
Olumsuz & Anadolu L. & 515 & 633.25 & & & & \\
Başa & Meslek L. & 394 & 598.91 & & & & \\
Çkma & Toplam & 1214 & & & & & \\
\hline
\end{tabular}

Tablo 10'a göre ergenlerin aktif başa çıkma ve kaçınan başa çıkma boyutu puanları okul türüne göre istatistiksel olarak anlamlı farkl1lık göstermektedir $(\mathrm{p}<0.05)$. Bu farklılık aktif başa çıkma boyutu için Fen Lisesi ile Meslek Lisesi'ndeki ergenler arasında, Fen Lisesi'ndeki ergenlerin puanları istatistiksel olarak daha yüksek; Anadolu Lisesi ile Meslek Lisesi'ndeki ergenler arasında, Anadolu Lisesi'ndeki ergenlerin puanları istatistiksel olarak daha yüksektir. Kaçınan başa çıkma boyutu için Fen Lisesi ile Anadolu Lisesi'ndeki ergenler arasında, Anadolu Lisesi'ndeki ergenlerin puanları istatistiksel olarak daha yüksektir. Ergenlerin olumsuz başa çıkma boyutu puanları okul türüne göre istatistiksel olarak anlamlı farklılık göstermemektedir ( $\mathrm{p}>0.05)$. Ergenlerin aktif başa çıkma, kaçınan başa çıkma ve olumsuz başa çıkma boyutu puanlarının algılanan başarı düzeyine göre farklılık gösterip göstermediğini belirlemek için yapılan Kruskal Wallis testi analizi sonuçları tablo 11'de verilmiştir.

Tablo 11.

Algllanan akademik başariya göre Kruskal Wallis testi sonuçları

\begin{tabular}{llllllll}
\hline & Başarı Düzeyi & $\mathrm{N}$ & Sıra Ort. & Ki-kare & sd & p & Farklılık \\
\hline \multirow{4}{*}{ Aktif Başa Çıkma } & Düşük & 68 & 503.10 & 8.211 & 2 & .016 & Düşük $<$ Orta \\
& Orta & 808 & 604.96 & & & & Düşük $<$ Yüksek \\
& Yüksek & 338 & 634.57 & & & & \\
& Toplam & 1214 & & & & & \\
\hline \multirow{3}{*}{ Kaçınan Başa Çıkma } & Düşük & 68 & 699.70 & 5.529 & 2 & .063 & \\
& Orta & 808 & 597.61 & & & & \\
& Yüksek & 338 & 612.59 & & & & \\
& Toplam & 1214 & & & & & \\
\hline & Düşük & 68 & 732.34 & 10,260 & 2 & .006 & Düşük $>$ Orta \\
& Orta & 808 & 606.18 & & & & Düşük > Yüksek \\
& Yüksek & 338 & 585.53 & & & & \\
\hline
\end{tabular}

Tablo 11'e göre ergenlerin aktif başa çıkma ve olumsuz başa çıkma boyutu puanları algılanan başarı düzeyine göre istatistiksel olarak anlamlı farklılık göstermektedir $(\mathrm{p}<0.05)$. Bu farklılık aktif başa çıkma boyutunda başarı düzeyini düşük olarak algılayan ergenlerin puanları başarı düzeyini orta ve yüksek olarak algılayan ergenlerin puanlarından istatistiksel olarak daha düşüktür. Olumsuz başa çıkma boyutunda ise başarı düzeyini düşük olarak algılayan ergenlerin puanları başarı düzeyini orta ve yüksek olarak algılayan ergenlerin puanlarından istatistiksel olarak daha yüksektir. Ergenlerin kaçınan başa çıkma boyutu puanları algılanan başarı düzeyine göre istatistiksel olarak anlamlı farklılık göstermemektedir $(\mathrm{p}>0.05)$. 
Öğrencilerin aktif başa çıkma, kaçınan başa çıkma ve olumsuz başa çıkma boyutu puanlarının lise seçim sürecine göre farklılık gösterip göstermediğini belirlemek için yapılan Kruskal Wallis testi analizi sonuçları tablo 12'de verilmiştir.

Tablo 12

Lise seçim sürecine göre Kruskal Wallis testi sonuçları

\begin{tabular}{|c|c|c|c|c|c|c|c|}
\hline & Tercih Nedeni & $\mathrm{N}$ & Sira Ort. & Ki-kare & sd & $\mathrm{p}$ & Farklilık \\
\hline \multirow[t]{5}{*}{ Aktif Başa Çıkma } & Aile & 57 & 515.62 & 13.330 & 3 & .004 & Aile $<$ Kendisi \\
\hline & Kendisi & 351 & 630.28 & & & & Aile $<$ Aile ve kendisi \\
\hline & Aile ve kendisi & 456 & 634.01 & & & & Kendisi $>$ Puan \\
\hline & Puan & 350 & 565.08 & & & & Aile ve kendisi>Puan \\
\hline & Toplam & 1214 & & & & & \\
\hline \multirow[t]{5}{*}{ Kaçınan Başa Çıkma } & Aile & 57 & 691.66 & 5.886 & 3 & .117 & \\
\hline & Kendisi & 351 & 580.75 & & & & \\
\hline & Aile ve kendisi & 456 & 608.05 & & & & \\
\hline & Puan & 350 & 619.90 & & & & \\
\hline & Toplam & 1214 & & & & & \\
\hline \multirow[t]{5}{*}{ Olumsuz Başa Çıkma } & Aile & 57 & 629.68 & 11.423 & 3 & .010 & Kendisi $<$ Puan \\
\hline & Kendisi & 351 & 584.29 & & & & Aile ve kendisi<Puan \\
\hline & Aile ve kendisi & 456 & 58386 & & & & \\
\hline & Puan & 350 & 657.96 & & & & \\
\hline & Toplam & 1214 & & & & & \\
\hline
\end{tabular}

Tablo 12 incelendiğinde ergenlerin aktif başa çıkma ve olumsuz başa çıkma boyutu puanları lise seçim sürecine göre istatistiksel olarak anlamlı farklılık göstermektedir $(\mathrm{p}<0.05)$. Bu farkl11ık aktif başa çıkma boyutu için aile isteğine göre seçim yapanlar ile kendi isteğine göre seçim yapanlar arasında; aile isteği ile seçim yapanlar ile aile ve kendi isteği ile seçim yapanlar arasında; kendi isteği ile seçim yapanlar ile puana göre seçim yapanlar arasında; aile ve kendi isteği ile seçim yapanlar ile puana göre seçim yapanlar arasındadır. Kendi isteğine ya da kendi ve ailesinin isteğine göre seçim yapanların aktif başa çıkma boyutu puanları istatistiksel olarak daha yüksektir. Olumsuz başa çıkma boyutunda ise farkl1lık kendi isteği ile seçim yapanlar ile puana göre seçim yapanlar arsında; aile ve kendi isteği ile seçim yapanlar ile puana göre seçim yapanlar arasındadır. Kendi isteğine ya da kendi ve ailesinin isteğine göre seçim yapanların olumsuz başa çıkma boyutu puanları istatistiksel olarak daha düşüktür.

\section{TARTIŞMA, SONUÇ ve ÖNERILER}

Araştırmanın genel amacı ergenlerin okula aidiyet duyguları ve başa çıkma stratejileri arasındaki ilişkiyi incelemektir. Ergenlerin okula aidiyet duygusu boyutu ile aktif başa çıkma boyutu arasında orta düzeyde pozitif yönde istatistiksel olarak anlamlı bir ilişki bulunmuştur. Ergenlerin okula aidiyet duygusu boyutu ile kaçınan başa çıkma ve olumsuz başa çıkma boyutları arasında negatif yönde istatistiksel olarak anlamlı ancak düşük düzeyde bir ilişki bulunmaktadır. Ergenlerin reddedilmişlik duygusu boyutu ile aktif başa çıkma boyutu arasında negatif yönde istatistiksel olarak anlamlı ancak düşük düzeyde bir ilişki bulunmuştur. Reddedilmişlik duygusu boyutu ile kaçınan başa çıkma ve olumsuz başa çıkma boyutları arasında pozitif yönde istatistiksel olarak anlamlı ancak düşük düzeyde bir ilişki bulunmaktadır. Ancak düşük korelasyon katsayılarının istatistiksel olarak anlamlı bulunmasında çalışma grubundaki birey sayısının fazla olmasının etkili olduğu düşünülmektedir. Literatürde bu konuda yapılmış bir çalışmaya rastlanmamıştır. Ancak alanyazında okula aidiyet duygusuyla yüksek başarı ve akademik motivasyon (Finn, 1989; Osterman, 2000); iyimserlik, benlik kavramı (Anderman, 2012), özsayg1 (Cemalcılar, 2010) gibi değişkenlerle pozitif yönde anlamlı ilişkiler saptanmıştır. Buna ilaveten depresyon, okul sorunları, sosyal red, devamsızlık (Anderman, 2012); disiplin sorunları, madde kullanımı (Beyer, 2008; Hallinan, 2008); okul tükenmişliği (Aksoy, 2017) vb. değişkenler ile de negatif yönde ilişkili olduğu sonucuna varılmıştır. Bu sonuçları destekler nitelikte okul gibi sosyal bir ortamın olumsuz ve yıkıcı davranışları önlediğinden söz edilmektedir (Akt. Doğan, 2015). Ersanlı ve Koçyiğit (2013) bireylerin ait olma ihtiyaçları karşılanmadığında bireylerin 
olumsuz, yıkıcı davranışlar gösterebileceği; devamında çaresizlik duygusuyla çeşitli girişimlerde bulunabileceği ve amaçsızlıkla mücadele vereceğini belirtmektedir. Ayrıca okula aidiyet duygusu düşük olan ergenlerin olumsuz davranışlar gösterebildikleri ve bu konuda bilinçli olmadıkları saptanmıştır (Ashford, 1997). Bu bilgiler ışığında okula aidiyet duygusu düşük olan ergenlerin herhangi bir sorunla karşılaştıklarında yıkıcı eylemlerle sonuçlanan olumsuz ve kaçınan başa çıkma stratejileri kullandıkları, okula aidiyet duygusu yüksek olan ergenlerin ise bu sayede aktif başa çıkma stratejisini kullanabildiği söylenebilir. Okula aidiyet duygusu yüksek olan ergenlerin sosyal destek mekanizmasi daha iyi çalışarak; aldığı iyi puanlarla, arkadaş ilişkileri, öğretmeni ile kurduğu bağ gibi okulun getirisi olan birçok faktör sayesinde karşılaştığ 1 olumsuz yaşantılarla aktif bir şekilde başa çıkmak için çaba sarf ettikleri söylenebilir.

Alanyazındaki çalışmalarda (Adelabu, 2007; Arastaman, 2006; Nichols, 2008; Goodenow, 1993; Sarı, 2013) kız ergenlerin erkek ergenlerin göre okula aidiyet duygusu boyutunda daha yüksek puanlar elde ettikleri, reddedilmişlik duygusu boyutundaki puanların erkek ergenlerin puanlarından daha düşük olduğu bulunmuştur. Buna ilişkin olarak kız ergenlerin okulu daha çok benimsedikleri bu sebeple okulu daha önemli görebilecekleri dolayısıyla da bağlllıkların daha fazla olabileceği belirtilmektedir (Utah, McMahon ve Furlow, 2008). Diğer yandan Altınsoy (2016) çalışmasında 11 ve 12.sınıflardaki Anadolu Lisesi öğrencileriyle yapılan çalışmada okula aidiyet duygusunun cinsiyete göre anlamlı farklılaşma olmadığını saptamıştır. Yapılan çalışmada ise erkek ergenlerin okula aidiyet duygusu boyutundan elde ettikleri puanların kız ergenlerin puanlarından manidar olarak daha yüksek olduğu görülmüştür. Okula aidiyet konusunun farklı bölgelerde çalışılmış olmasının bu farklılı̆̆a sebep olduğu düşünülebilir. Çalışma bulgularında bu sonuca ulaşılmasında örneklemi oluşturan okulların kız öğrenci-erkek öğrenci sayıları, okulların niteliği (Meslek Lisesi, Anadolu Lisesi, Fen Lisesi) gibi faktörler de etkili olabilir. Çalışma grubunun bir bölümünü oluşturan Meslek Lisesinin, kız meslek lisesi olduğu ve kız öğrenci sayısının erkek öğrenci sayısına göre fazla olduğu bilinmelidir.

Çalışmanın bir diğer bulgusuna göre de en yüksek okula aidiyet duygusu puanı Fen Lisesi öğrencilerine ait iken, en düşük okula aidiyet duygusu puanları Meslek Lisesi öğrencilerine aittir. En yüksek reddedilmişlik duygusu puanı Meslek Lisesi öğrencilerine ait iken, en düşük reddedilmişlik duygusu boyutu puanları Fen Lisesi öğrencilerine aittir. Bunu destekler nitelikte Gökşen, Yükseker, Açıkalın ve Zenginobuz (2012) çalışmasında kız meslek lisesi öğrencilerinin ve mezunlarının bu lisedeki eğitimi yeterli bulmadığı, istihdam oranlarından memnuniyet duymadıkları ve okullarını itibarlı olmadığını ifade ettiklerini saptamıştır. Araştırmada elde edilen bu bulgu da göz önüne alındığında Meslek Lisesi örneklem grubundaki kız öğrencilerin fazla ve okula aidiyet duygularının düşük olması, erkek öğrencilerin okula aidiyet duygusu puanlarının kız öğrencilere oranla daha fazla çıkması üzerinde etkili olabilir.

Yapılan incelemede 9.sınıf ergenlerin üst sinıflarda öğrenim gören ergenlere göre ve 10.sınıftaki ergenlerin 12. Sınıfta öğrenim gören ergenlere göre okula aidiyet duygusu puanlarının daha yüksek olduğu görülmektedir. Ayrıca sınıf düzeyi arttıkça reddedilmişlik duygusu boyutu puanlarının da arttığı saptanmıştır. Sarı (2013) çalışmasında okula aidiyet duygusu ölçeği toplam puanlarının sınıf düzeyi arttıkça düştüğünü ve en yüksek ortalamanın 9.sınıf öğrencilerine ait olduğunu belirtmektedir. Farklı çalışmalarda ise (Altınsoy, 2016; Goodenow, 1993; Hagborg, 1994) sınıf düzeyine göre okula aidiyet duygularının anlamlı bir şekilde farklılaşmadığı bulunmuştur. Bulguların bu yönde şekillenmesine ortaokuldan lise kademesine henüz başlayan 9.sınıftaki ergenlerin ve alan-dal seçimi (eşit ağırlık, sözel, sayısal, çocuk gelişimi, kimya teknolojisi vb.) yapan 10.sınıftaki ergenlerin okula ve bölümlerine yönelik ilgilerinin yüksek olmasının okula aidiyet duygusu puanlarına olumlu katk1 sağlamış olduğu düşünülebilir. Ayrıca 11. ve 12. sınıflarda bir üst öğrenim kurumu olan üniversiteye hazırlık çalışmalarının yoğunlukta olması da bu kademedeki ergenlerin okula aidiyet duygusu puanlarını olumsuz yönde etkilemiş olabilir. Sonuç olarak böyle bir durumda daha fazla araştırmaya ihtiyaç duyulduğu, yapılacak çalışmaların alandaki bir eksikliği gidereceği düşünülmektedir.

Araştırmanın bir diğer bulgusu en yüksek okula aidiyet duygusu boyutu puanı Fen Lisesi'ndeki ergenlere ait iken, en düşük okula aidiyet duygusu boyutu puanı Meslek Lisesi'ndeki ergenlere ait olmasıdır. Ayrıca en yüksek reddedilmişlik duygusu boyutu puanı Meslek Lisesi'ndeki ergenlere ait iken, en düşük reddedilmişlik duygusu boyutu puanı Fen Lisesi'ndeki ergenlere aittir. Bu konuyla ilgili alanyazında incelendiğinde Meslek Lisesindeki ergenlerin bu lise türünü tercih etme nedenleri arasında mesleğe olan ilgileri ve yüksek bir not ortalaması sağladığında istediği bölümü seçebilme imkanına sahip olmasının yer aldığı görülmektedir (Yavuz-Mumcu, Mumcu ve Cansız-Aktaş, 2012). Bu bakış 
açısıyla Meslek Lisesi'ndeki ergenler kendilerini istihdam konusunda şanslı görebilir. Ancak öğrencilerin not ortalamaları düşük olduğunda ve istedikleri alana yönelemedikleri durumlarda da üniversite sınavına ilişkin olumsuz duygu durumu içerisine girebilirler. Yüklendikleri bu duygu Meslek Lisesi'ndeki ergenlerin okula bağlılık düzeylerini olumsuz yönde etkilemiş olabilir. Beklenen puanı elde edemeyen ergenin bir zorunluluk dahilinde Meslek Lisesine yönelmesi ve zorunlu eğitimin esasları gereği ortaöğretimini tamamlama isteği bu lise türündeki öğrencilerde görülen özelliklerden olabilmektedir. Bu faktörler meslek lisesindeki ergenlerin okula ilişkin tutumunu olumsuz yönde etkileyebilir. Ayrıca Gökşen ve diğerlerinin (2012) çalışmasında kız meslek lisesi öğrencilerinin okullarına ilişkin olumsuz tutumu olduğu saptanmıştır. Okullarına ilişkin olumsuz tutuma sahip olan meslek lisesi öğrencilerinin okula aidiyet duygularının düşük olmasının bu noktada beklenen bir veri olduğu söylenebilir.

Çalışmada en yüksek okula aidiyet duygusu boyutu puanının başarı düzeyini yüksek olarak algılayan ergenlere, en düşük okula aidiyet duygusu boyutu puanının başarı düzeyini düşük olarak algılayan ergenlere ait olduğu bulunmuştur. Ayrıca en yüksek reddedilmişlik duygusu boyutu puanı başarı düzeyini düşük olarak algılayan ergenlere ait iken, en düşük reddedilmişlik duygusu boyutu puanı başarı düzeyini yüksek olarak algılayan ergenlere aittir. Sarı da (2012) lise öğrencilerinin oluşturduğu örneklemde yaptığı çalışmasında benzer sonuçlara ulaşmıştır. Aksoy (2017) çalışmasında başarı puanı düşük öğrencilerin okul tükenmişliklerinin fazla olduğunu ifade etmiştir. Bellici (2015) ortaokul öğrencileri ile yaptı̆̆ puanlarının daha yüksek olduğunu saptamıştır. Dolayısıyla okuldaki akademik başarının okulu sahiplenmeyi ve okula ait olma duygusunu yordadığı sonucuna varılabilir. Ancak literatür incelendiğinde, Capps'in (2003) ortaokul öğrencileri ile yaptığı çalışmasında okula aidiyet duygusu ile akademik başarı arasında anlamlı ilişki olmadığı sonucuna ulaştığı görülmektedir. Kılıçoğlu (2014) da İngiltere'de 11-18 yaş arası ergenlerin örneklemi olduğu çalışmasında okula aidiyet duygusu ve akademik başarı arasında ilişki olmadığı sonucuna ulaşmıştır. Yapılan araştırmada okula aidiyet duygusu ve akademik başarı arasında ilişki bulunmasına birçok faktör etki etki etmiş olabilir. Örneğin; okul başarısı düşük olduğu için bu durumu kendisi dışında başka faktörlere dayandıran bireylerin okula aidiyetlerinin düşük olduğu söylenebilir. Birey reddedilmişlik hissi ile yaşadığı başarısızlık durumunun nedenleri ve sonuçlarına ilişkin bir baskılama gerçekleştiriyor olabilir. Bu aynı zamanda sorumluluk duygusundan kaçmanın da bir yöntemi olarak görülüyor olabilir.

Ergenlerin lise seçim süreçleri ile ilgili bulgu incelendiğinde ailesi ve kendi isteği doğrultusunda seçim yapan ergenlerin okula aidiyet duygusu boyutu puanlarının diğer ergenlere göre daha yüksek olduğu görülmektedir. Ek olarak seçim sürecini puan doğrultusunda yaptıklarını belirten ergenlerin diğer ergenlere göre reddedilmişlik duygusu boyutu puanlarının daha yüksek olduğu görülmüştür. Literatür incelendiğinde bu konuda yapılmış bir çalışmaya rastlanmamıştır. Ancak kendisi ve ailesinin isteğiyle lise seçimini gerçekleştiren ergenlerin okula aidiyet duygularının yüksek olması ebeveynlerini, bu süreçte sosyal destek olarak görmelerinden ve bu sayede okula ilişkin olumlu tutum geliştirmelerinden kaynaklanıyor olabilir. Ayrıca bu bağlamda ebeveyn ve çocuğun ortak karar almasının önemli olduğu sonucuna da varılabilir. Bu çalışmanın çarpıcı sonucu ise beklenenin aksine kendi isteği ile seçim yapan ergenlerin okula aidiyet duygusunda en yüksek puanı alamamış olmalarıdır. Ergenlerin özellikleri dikkate alındığında anne baba ile çatışma yaşamaları, kendi görüşleri doğrultusunda hareket etme istekleri ön plana çıkan ergenlik dönemi özellikleridir. Ancak bu çalışmada hem ailenin hem de kendisinin isteği olan bir okul seçim süreci yaşamış olmanın okula aidiyeti arttırdığ görülmektedir. Puan gerekçesiyle okul seçen ergenlerin de okula aidiyet duyguları ile ilgili bir çalışmaya literatürde rastlanmamıştır. Ancak öğrencilerin elde ettikleri puandan kaynaklı olarak seçim yapacağı liselerin yapacağı liselerin kısıtlı olması bu sonucu ortaya çıkarmış olabilir. Beklediği puanı alamayan ergen, istemediği bir okula yerleşmiş, aynı zamanda gelecekte yapmayı planladığı meslekten uzaklaşmak zorunda kalmış olabilir. Bu durum da ergenlerin okula aidiyet duygusuna olumsuz etki ediyor olabilir.

Ergenlerin başa çıkma stratejileri cinsiyet değişkenine göre incelendiğinde aktif başa çıkma, kaçınan başa çıkma ve olumsuz başa çıkma alt boyutlarının cinsiyete göre istatistiksel olarak anlamlı farklılık göstermediği bulunmuştur. Alanyazında Özer (2001) lise kademesindeki öğrencilerle yaptığı çalışmasında kız öğrencilerin erkek öğrencilere göre sosyal destek ve kaçınma stratejilerini daha fazla kullandıkları sonucunu bulmuştur. Çiftçi (2002) de ergenlerin stresle başa çıkma yolları ve strese karşı dayanıklılıklarını incelediği çalışmasında kız öğrencilerin kendilerini daha fazla suçladıkları sonucuna 
ulaşmıştır. Yapılan çalışmada ise başa çıkma stratejilerinin cinsiyete göre anlamlı farklılık göstermemesi, başa çıkma stratejilerinin daha çok mantıksal çıkarsama yapma, hipotez kurma, varsayımsal düşünme vb. bilişsel sürece yönelik öğeleri içermesinden kaynaklanıyor olabilir. $\mathrm{Bu}$ durumdan ergenlerin başa çıkma stratejilerinin cinsiyet değişkenine göre farklılık olmaması hususunda ileri çalışmalar yapılması gerektiği anlaşılmaktadır. Konuyla ilgili yapılacak çalışmalardan elde edilecek sonuçlarla alanyazında önemli bir eksiklik de giderilmiş olacaktır.

Araştırma bulgularında ergenlerin başa çıkma stratejilerinin alt boyutu olan kaçınan başa çıkma puanlarının, ergenlerin sınıf düzeyine göre istatistiksel olarak anlamlı şekilde farklılaştığı görülmektedir. Bu farklılık 10. Sinıftaki ergenler ile 9. Sinıf ve 12. Sinıf ergenler arasında olup, 10. sınıftaki ergenlerin kaçınan başa çıkma boyutu puanları 9. Sınıf ve 12. Sınıftaki ergenlerin kaçınan başa çıkma boyutu puanlarından istatistiksel olarak daha yüksektir. Literatürde sınıf düzeyi ve başa çıkma stratejileri arasındaki ilişkiye dayalı bir bulgu bulunamamıştır. Ancak bu sonucun ortaya çıkmasında ergenlerin yaklaşık olarak orta ergenlik döneminde olmasından kaynaklanabilir. Bu dönemde çocukluk ve yetișkinlik arasında kalmıș olmaları, kendilerini tanıma konusunda eksikliklerinin fazla olması, başarılı-başarısız oldukları alanları tam olarak saptayamamaları sebebiyle stres yaratan bir duruma ilişkin "kaçınma" davranışını göstermiş olabilirler. Ayrıca okulun rehberlik servisinin desteğine ve rehberliğine ihtiyaçları olduğu sonucuna da varılabilir.

Aktif Başa Çıkma boyutunda okul türüne göre istatistiksel anlamda farklılık olduğu görülmektedir. Buna göre başa çıkma stratejilerinin aktif başa çıkma alt boyutunda en yüksek puanı alan Fen Lisesi'nde öğrenim gören ergenler olurken en az puanın Meslek Lisesi'ndeki ergenlere ait olduğu saptanmıştır. Elde edilen bulguya ilişkin bir çalışmaya literatürde rastlanmamıştır. Ancak Yıldırım, Hacıhasanoğlu, Karakurt ve Türkleş (2011) yaptıkları çalışmada farklı okul türlerindeki (Fen Lisesi, Anadolu Lisesi ve Düz Lise) öğrencilerin problem çözme becerilerini ve problem çözme becerilerini etkileyen faktörleri (yaş, cinsiyet, okul türü aylık gelir vb.) incelemişlerdir. Hacıhasanoğlu ve arkadaşları (2011) Fen lisesinde öğrenim gören ergenlerin problem çözme becerileri puanlarının daha yüksek olduğunu saptamışlardır. Bulguların bu şekilde sonuçlanmasında okulun çok yönlü gelişim sağlayan bir kurum olmasının etkisi olduğu düşünülebilir. Çünkü okulun akademik anlamda gelişim sağlamasının yanı sıra bireye içinde yaşadığı kültüre uyum sağlaması işlevini de yürütmektedir (Yavuzer, 2007). Ayrıca MEB Ortaöğretime Geçiş Yönergesi'ne göre de merkezi sınavla öğrenci alan okullar içerisinde Fen Liselerinin fazla olduğu ve nitelikli okul olarak adlandırıldığı görülmektedir. Dolayısıyla bulguların bu yönde şekillenmesinde bu faktörlerin birleşiminin etkili olduğu sonucuna varılabilir.

Ergenlerin başa çıkma stratejileri algılanan başarı düzeyine göre incelendiğinde aktif başa çıkma boyutunda başarı düzeyini düşük olarak algılayan ergenlerin puanları başarı düzeyini orta ve yüksek olarak algılayan ergenlerin puanlarından istatistiksel olarak daha düşüktür. Olumsuz başa çıkma boyutunda ise başarı düzeyini düşük olarak algılayan ergenlerin puanları başarı düzeyini orta ve yüksek olarak algılayan ergenlerin puanlarından istatistiksel olarak daha yüksektir. Literatür incelendiğinde Çiftçi (2002) çalışmasında akademik olarak başarılı ergenlerin problem çözmeye dayalı başa çıkma stratejilerini kullandıklarını belirlemiştir. Alver (2005) ise ergenlerin problem çözme becerileri ve akademik başarılarını çeşitli değişkenlere göre (cinsiyet, en uzun yaşanılan yer, bölüm vb.) incelediği çalışmasında bireylerin problem çözme becerileri puan ortalamalarıyla akademik başarı arasında anlamlı bir ilişki olmadığını saptamıştır.

Yenidünya (2005) çağdaş eğitimin gereği olarak okulların çalışma alışkanlığı kazandırma yönü olduğu gibi bireylerin otokontrol becerisi, olumlu davranış, yaratıcı ve gerçekçi düşünme becerileri geliştirme, ilgi alanları edinebilme gibi kazanımlar da sağladığını belirtmektedir. Bu doğrultuda okulun hem akademik hem de psikolojik açıdan destekleyici bir rolü olduğu yorumuna varılabilir. Yapılan çalışmada sonuçların bu yönde şekillenmesinde akademik başarının ergeni psikolojik açıdan desteklemesinin etkili olduğu düşünülebilir. Ayrıca akademik başarısı yüksek olan öğrencilerin mantıksal çıkarsamalarının işlevsel ve nitelikli olması sebebiyle aktif başa çıkma stratejilerini kullanabildikleri sonucuna ulaşılabilir.

Lise seçim süreci ile başa çıkma stratejileri incelendiğinde kendi ve ailesinin isteğine göre tercih yapanların aktif başa çıkma boyutu puanlarının istatistiksel olarak daha yüksek olduğu görülmüştür. Ek olarak kendi ve ailesinin isteğine göre tercih yapanların olumsuz başa çıkma boyutu puanları istatistiksel olarak daha düşük olduğu saptanmıştır. Literatürde bu konu üzerine çalışma olmadığı görülmektedir. Ancak bulguların bu yönde şekillenmesinde ailesinden sosyal destek gören bireyin 
duygusal açıdan desteklenmesiyle sağlıklı başa çıkma stratejilerini kullanabilmesinin etkili olduğu düşünülebilir.

Lise seçim süreci ile başa çıkma stratejileri incelendiğinde kendi ve ailesinin isteğine göre tercih yapanların aktif başa çıkma boyutu puanlarının istatistiksel anlamda daha yüksek olduğu saptanmıştır. Ayrıca kendi ve ailesinin isteğine göre tercih yapanların olumsuz başa çıkma boyutu puanları istatistiksel anlamda daha düşük olduğu görülmüştür. Literatürde bu konu üzerine çalışma olmadığı görülmektedir. Ancak bulguların bu yönde şekillenmesinde ailesinden sosyal destek gören bireyin duygusal açıdan desteklenmesiyle sağlıklı başa çıkma stratejilerini kullanabilmesinin etkili olduğu düşünülebilir.

Çalışma sonucuna dair öğrencilerin okula aidiyet duygusunun geliştirilmesiyle ilgili öneriler getirilebilir. Örneğin; okulda yapılacak olan sosyokültürel etkinliklerin artırılmasıyla öğrencinin okulla olan bağını güçlendireceği ve ergenin kendisini okulun bir parçası olarak görmesine katkı sağlayacağ düşünülebilir. Okulun fiziksel donanım ve koşullarının artırılmasıyla da olumlu sonuçlar elde edilebilir. Kariyer Günleri Etkinliklerinde ilgili okullardan mesleğe atılmış kişilerin hazırladığı seminerler okullardaki ergenlerin okula aidiyet duygularını güçlendirebilir. Ortaokul kademesindeki ergenlere Liseye Giriş Sınavı tanıtımı yapılırken velilere de bu konuda rehberlik hizmeti sağlanmasının çocuk ve anne-babanın ortak bir paydada buluşmasını sağlayarak ergenin gideceği okula ilişkin olumlu tutum oluşturmasına yardımcı olacağı düşünülmektedir. Türkiye'nin farklı illerinde ve özel öğretim kurumları da eklenerek geniş kapsamda sonuçlar elde edilebilir. Başka araştırmalarda farklı değişkenler kullanılarak ya da değişken sayısı artırılarak (anne-baba eğitim durumu, okulda rehberlik servisinin olup-olmaması vb.) geniş çaplı bir çalışma oluşturulabilir. Ergenlerin eğitim süreçleri boyunca her sınıfta okula aidiyet duygusu ve başa çıkma stratejileri değişkenlerine ilişkin ölçümleri alınarak, boylamsal bir çalışma yapılabilir. Bu sayede bu değişkenlere ilişkin aynı ergenlerin zaman içindeki gelişimlerini incelemek mümkün olabilir. Yükseköğretimde okula aidiyet duygusu ile ilgili bir çalışmaya ulaşılamamıştır. Bu kavramın ele alınmasıyla okula aidiyet duygusuyla ilgili tüm eğitim öğretim basamaklarını kapsayan geniş çaplı bir çalışma yapılabilir.

\section{KAYNAKÇA}

Adams, J.F. Ergenliği anlamak. J.F. Adams (Ed) Ergenliği anlamak (13-47) (Çev. A. Dönmez) B. Onur (Ed.). Ankara: İmge Yayınevi, 1995.

Adelabu, D. H. (2007). Time perspective and school membership as correlates to academic achievement among African American adolescents. Adolescence, 42, 525-539.

Ağargün, M. Y., Befliroğlu, L., Kıran, Ü. K., Özer, Ö. A. ve Kara, H. (2005). COPE (Başa çıkma tutumlarını değerlendirme ölçeği): psikometrik özelliklere ilişkin bir ön çalışma. Anadolu Psikiyatri Dergisi, 6(1), 221-226.

Aksoy, M. Ortaöğretim öğrencilerinin okul tükenmişliği ile okul aidiyetleri arasındaki ilişkininçeşitli değişkenler açısından araştırılması. Yayımlanmamış Yüksek Lisans Tezi, İstanbul Kültür Üniversitesi, Sosyal Bilimler Enstitüsü, İstanbul.

Alaca, F. (2011). İki dilli olan ve olmayan öğrencilerde okul yaşam kalitesi algisı ve okula aidiyet duygusu iliş̧kisi. Yayımlanmamış Yüksek Lisans Tezi, Çukurova Üniversitesi, Sosyal Bilimler Enstitüsü. Adana.

Altınsoy, F. (2016). Ergenlerde okula aidiyet duygusunun yordayıcısı olarak yaşam amaçları ve bağlanma stilleri, Yayımlanmamış Yüksek Lisans Tezi, Gaziosmanpaşa Üniversitesi, Eğitim Bilimleri Enstitüsü, Tokat.

Altınsoy, F. ve Karakaya Özyer, K. (2018). Liseli ergenlerde okula aidiyet duygusu: umutsuzluk ve yalnızlık ile ilişkileri. İlkögretim Online. 17(3). 1751-1764.

Alver, B. (2005). Üniversite öğrencilerinin problem çözme becerileri ve akademik başarılarının çeşitli değişkenlere göre incelenmesi. Atatürk Eğitim Fakültesi Eğitim Bilimleri Dergisi. 21(2), 75-88.

Altık S. (2011). Üniversite öğrencilerinin utangaçlık ve başa çıkma stratejileri iliş̧kilerinin incelenmesi. Yayımlanmamış Yüksek Lisans Tezi. Eskişehir Osmangazi Üniversitesi. Sağlık Bilimleri Enstitüsü, Eskișehir.

Arastaman, G. (2006). Ankara ili lise birinci sını öğrencilerinin okula bağlllık durumlarına ilişkin öğrenci, ögretmen ve yöneticilerin görüşleri. Yayımlanmamış yüksek lisans tezi, Ankara Üniversitesi, Ankara.

Arıkan G. (2015). Spor lisesi ve Anadolu Lisesi ögrrencilerinde okula aidiyet duygusu ve okul yaşam kalitesinin incelenmesi: Güneydoğu Anadolu Bölgesi örneği. Yayımlanmamış Doktora Tezi. Çukurova Üniversitesi, Sağlık Bilimleri Enstitüsü, Adana. 
Ashford, M. W. (1997) . Preventing school violence by building connect edness: a local initiative. Medicine Confilictand Survival,13, 57-62.

Aydoğdu T. (2013). Bağlanma stilleri, başa çıkma stratejileri ile psikolojik dayanıklılık arasındaki ilişkinin incelenmesi. Yayımlanmamış Yüksek Lisans Tezi. Gazi Üniversitesi, Eğitim Bilimleri Enstitüsü, Ankara.

Balıkcı A. (2010). Antisosyal kişilik bozukluğunda kendine zarar verme davranışı, disosiyatif yaşantılar ve başa çıkma tutumları. Yayımlanmamış Tıpta Uzmanlık Tezi. Gülhane Askeri Tıp Akademisi, İstanbul.

Bahadır, A. (1994). Ergenlik döneminde dini şüphe ve tereddütler. Yayımlanmamış Yüksek lisans Tezi, Uludağ Üniversitesi, Sosyal Bilimler Enstitüsü, Bursa.

Bedel, A., Işık, E. ve Hamarta, E (2014). Ergenler için başa çıkma ölçeğinin (EBÇÖ) geçerlik ve güvenirlik çalışması. Eğitim ve Bilim, 39(176), 227-235.

Bedel, A. ve Ulubey, E. (2015). Ergenlerde başa çıkma stratejilerini açıklamada bilişsel esnekliğin rolü. Elektronik Sosyal Bilimler Dergisi, 14(55), 291-300.

Burger, J. M. (2006). Kişilik. (Çev. İ. Deniz ve E. Sarığlu). İstanbul: Kaknüs Yayınları.

Booker, K. C. (2004). Exploring school belonging and academic achievement in African American adolescents. Curriculum and Teaching Dialogue, 6 (2), 131-143.

Bellici, N. (2015). Ortaokul öğrencilerinde okula bağlanmanın çeşitli değişkenler açısından incelenmesi. Abant İzzet Baysal Üniversitesi Ĕ̈itim Fakültesi Dergisi. 15(1), 48-65.

Capps, M. A. (2003). Characteristics of a sense of belonging and its relationship to academic achievement of students in selected middle schools in region $\imath v$ and $v \imath$ educational service centers. Unpublished Doctoral Dissertation, A\&M University, Texas.

Çiftci, S. (2015). Ergenlik dönemindeki ögrencilerin asilik davranışları ile siber zorba ve siber mă̆dur olma düzeyleri arasındaki ilişkinin incelenmesi. Yayımlanmamış Yüksek Lisans Tezi. Fatih Üniversitesi, Sosyal Bilimler Enstitüsü, İstanbul.

Doğan, A. (2015). Ortä̈ğretim öğrencilerinin kural dışı davranış göstermelerinde öğretim hayatlarını denetleyememe inancı, özsaygl ve okula aidiyet duygularının rolü. Yayımlanmamış Yüksek Lisans Tezi. Mersin Üniversitesi, Eğitim Bilimleri Enstitüsü, Mersin.

Doğan, T., Sapmaz, F. ve Totan, T. (2011). Beden imgesi baş etme stratejileri ölçeğinin Türkçe uyarlaması: geçerlik ve güvenirlik çalışması. Anadolu Psikiyatri Dergisi, 12,121-129.

Eroğlu, E. (2001). Ailenin çocuklarda problem çözme becerisi üzerine etkisi: Adapazarı Örneği. Yayımlanmamış Yüksek Lisans Tezi, Sakarya Üniversitesi Sosyal Bilimler Enstitüsü, Sakarya.

Ersanlı, K. , Koçyiğit, M. (2013). Ait olma ölçeğinin psikometrik özellikleri. Turkish Studies. 8(12), 751-764.

Eryılmaz, A. (2009). Ergenlik döneminde stres ve başa çıkma. Yüzüncü Yıl Üniversitesi Eğitim Fakültesi Dergisi, $6(2), 20-37$.

Fredericks, J. A., Blumenfeld, P. C., ve Paris, A. H. (2004). School engagement: potential of the concept, and state of the evidence. Review of Educational Research, 74 (1), 59-109.

Finn, J. (1989). Withdrawing from school. Review of Educational Research, 59, 117-142.

Gallagher J.M ve Mansfeild, R.S. (1995) Ergenlikte bilişsel gelişim J.F. Adams (Ed) Ergenliği anlamak (49-80) (Çev. D. Öngen) B. Onur (Ed.). Ankara: İmge Yayınevi.

Geçtan, E. (1999). Psikanaliz ve sonrası. İstanbul: Remzi Kitabevi.

Günalan N. (2018). Ortaokul öğrencilerinin okul yaşam kalitesini, okula aidiyet duygunu ve okul iklimini neler etkilemektedir? Yayımlanmamış Yüksek Lisans Tezi. Adnan Menderes Üniversitesi, Sosyal Bilimler Enstitüsü, Aydın.

Goodenow, C. (1993).The Psychological sense of school membership among adolescents: scale development and educational correlates. Psychology in the Schools, 30, 79-90.

Gökşen F., Yükseker D., Alnıaçık A. ve Zenginobuz Ü. (2011). Kız teknik ve meslek liseleri kapsaml değerlendirme notu. İstanbul: Koç Üniversitesi Sosyal Politika Merkezi

Hagborg, W. J. (1994). An exploration of school membership among middle and high school students. Journal of Psychological Assessment, 12, 312-323.

Hallinan, M. T. (2008). Teacher influences on students' attachment to school. Sociology of Education, 81, 271283.

İhtiyaroğlu, N. ve Demir, E. (2015). Farklı denetim odağına sahip öğrencilerin okula bağlılık düzeylerinin incelenmesi. KSBD, Hüseyin Hüsnü Tekışı Özel Sayısı 1(7), 281-295.

Karasar, N. (2008) Bilimsel araştırma yöntemi: kavramlar, ilkeler, teknikler, 3A Araştırma Eğitim, Danışmanlık Ltd. Şti. , Ankara

Kılıçoğlu G. (2014). İngiltere'deki öğretmenlerin çok kültürlü öğretim yeterlilikleri ile türk öğrencilerin kültürleşme tercihlerinin okula aidiyet duygusu ve akademik başarlyla ilişkisi. Yayımlanmamış Doktora Tezi. Eskişehir Osmangazi Üniversitesi, Eğitim Bilimleri Enstitüsü, Eskişehir

Kulaksızoğlu, A. (2004). Ergenlik psikolojisi. Remzi Kitabevi, İstanbul. 
Kurt T. (2013). Ebeveynleri boşanmış ergenlerin yılmazlık, benlik saygısı, başa çıkma ve psikolojik belirtiler arasındaki ilişkinin incelenmesi: yılmazlığın aracı rolü. Yayımlanmamış Yüksek Lisans Tezi. Gazi Üniversitesi, Eğitim Bilimleri Enstitüsü, Ankara.

Millî Eğitim Bakanlığı (MEB) (2013). Ortaöğretim kurumları yönetmeliği. 07.09.2013 tarihli ve 28758 sayılı Resmi Gazete.

Mumcu Y. H. , Mumcu İ. ve Aktaş C. M. (2012). Meslek lisesi öğrencileri için matematik. Amasya Üniversitesi Ĕ̈itim Fakültesi Dergisi 1(2); 180-195.

Nichols, S. L. (2008). An exploration of students's belongingness beliefs in one middle school. The Journal of Experimental Education, 76(2), 145-169.

Oluğ F. (2011). Erinlik dönemindeki öğrencilerde dini tutum ve davranışlar (sakarya örneği). Yayımlanmamış Yüksek Lisans Tezi. Sakarya Üniversitesi; Sosyal Bilimler Enstitüsü, Sakarya.

Osterman, F. K. (2000). Students' need for belonging in the school community. Review of Educational Research, $70(3), 323-367$.

Öngen, D. (2002). Ergenlerde sorunlarla başa çıkma davranışları. Eğitim ve Bilim, 27(125), 54-61

Özer, İ. (2001). Ergenlerin stres yaşantılarında kullandıkları başa çıkma stratejilerinin benlik imajı ile ilişkisi. Yayımlanmamış Yüksek Lisans Tezi. Çukurova Üniversitesi Sosyal Bilimler Enstitüsü, Adana.

Özgök A. (2013). Ortaokul öğrencilerinde okula aidiyet duygusunun arkadaşlarla bağlllık düzeyinin ve empatik sınıf atmosferi algısının incelenmesi. Yayımlanmamış Yüksek Lisans Tezi. Çukurova Üniversitesi, Sosyal Bilimler Enstitüsü, Adana.

Özdemir, S. , Sezgin, F. , Şirin, H. , Karip, E. ve Erkan S. (2010). İlköğretim öğrencilerinin okul iklimine ilişkin algılarını yordayan değişkenlerin incelenmesi. Hacettepe Üniversitesi Eğitim Fakültesi Dergisi. 38 (1); 213-224.

Sarı, M. (2011). Adaptation of the psychological sense of school membership scale to Turkish. Global Journal of Human Social Science. 15(2), 59-64.

Sarı, M. (2012). Lise öğrencilerinde okula aidiyet duygusu. Anadolu Üniversitesi Sosyal Bilimler Dergisi,1,147160.

Spirito, A., Stark, L.J., ve Williams, C. (1988). Development of a brief coping checklist for use with pediatric populations. Journal of Pediatric Psychology, 13(4), 555-574.

Türküm, A.S., Kızıltaş, A. ve Sarıyer, A. (2004). Anadolu üniversitesi psikolojik danışma ve rehberlik merkezinin hedef kitlesinin psikolojik ihtiyaçlarına ilişkin ön çalışma. Türk PDR Dergisi, 21, 15-27.

Uygur, S. S. (2017). Ergenlerin bilinçli farkındalı̆̆ının yordanmasında başa çıkma stilleri, empati ve duygusal düzenlemenin rolü. Yayımlanmamış Yüksek Lisans Tezi. Dokuz Eylül Üniversitesi, Sosyal Bilimler Enstitüsü, İzmir.

Yavuzer, H. (2007). Çocuk Psikolojisi, Remzi Kitabevi, İstanbul.

Yenidünya, A. (2005). Lise ögrencilerinde rekabetçi tutum, benlik saygısı ve akademik başarı ilişkisi. Yayımlanmamış Yüksek Lisans Tezi. Marmara Üniversitesi, Eğitim Bilimler Enstitüsü, İstanbul.

Yıldırım, A., Hacıhasanoğlu, R. , Karakurt, P. ve Türkleş, S. (2011). Lise öğrencilerinin problem çözme becerileri ve etkileyen faktörler. Uluslararası Ínsan Bilimleri Dergisi. 8 (1), 905-921

Yörükoğlu, A. (2000). Gençlik çă̆ 